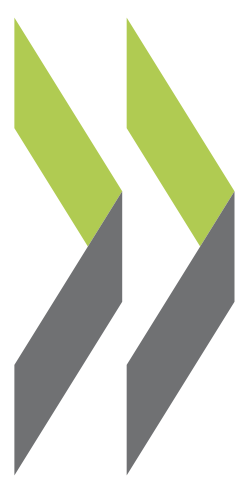

OECD Economics Department Working Papers No. 1188

Boosting Growth

and Reducing Informality

in Mexico

\title{
Sean Dougherty
}

https://dx.doi.org/10.1787/5js4w28dnn28-en 
Organisation de Coopération et de Développement Économiques

Organisation for Economic Co-operation and Development

06-Mar-2015

ECONOMICS DEPARTMENT

English - Or. English

Cancels \& replaces the same document of 05 March 2015

BOOSTING GROWTH AND REDUCING INFORMALITY IN MEXICO

ECONOMICS DEPARTMENT WORKING PAPERS No. 1188

By Sean M. Dougherty

OECD Working Papers should not be reported as representing the official views of the OECD or of its member countries. The opinions expressed and arguments employed are those of the author(s).

Authorised for publication by Robert Ford, Deputy Director, Country Studies Branch, Economics Department.

All Economics Department Working Papers are available through OECD's Internet website at www.oecd.org/eco/workingpapers

JT03371708

Complete document available on OLIS in its original format

This document and any map included herein are without prejudice to the status of or sovereignty over any territory, to the delimitation of international frontiers and boundaries and to the name of any territory, city or area. 
OECD Working Papers should not be reported as representing the official views of the OECD or of its member countries. The opinions expressed and arguments employed are those of the author(s).

Working Papers describe preliminary results or research in progress by the author(s) and are published to stimulate discussion on a broad range of issues on which the OECD works.

Comments on Working Papers are welcomed, and may be sent to the Economics Department, OECD, 2 rue André-Pascal, 75775 Paris Cedex 16, France, or by e-mail to eco.contact@oecd.org.

This document and any map included herein are without prejudice to the status of or sovereignty over any territory, to the delimitation of international frontiers and boundaries and to the name of any territory, city or area.

The statistical data for Israel are supplied by and under the responsibility of the relevant Israeli authorities. The use of such data by the OECD is without prejudice to the status of the Golan Heights, East Jerusalem and Israeli settlements in the West Bank under the terms of international law.

\section{(C) OECD (2015)}

You can copy, download or print OECD content for your own use, and you can include excerpts from OECD publications, databases and multimedia products in your own documents, presentations, blogs, websites and teaching materials, provided that suitable acknowledgment of OECD as source and copyright owner is given. All requests for commercial use and translation rights should be submitted to rights@oecd.org 


\section{ABSTRACT/RÉSUMÉ \\ Boosting Growth and Reducing Informality in Mexico}

Mexico has embarked on a bold package of structural reforms that will help it to break away from three decades of slow growth and low productivity. Major structural measures have been legislated to improve competition, education, energy, the financial sector, labour, infrastructure and the tax system, among many, and implementation has started in earnest. If fully implemented, these reforms could increase annual trend per capita GDP growth by as much as one percentage point over the next ten years, with the energy reforms having the most front-loaded effects. Beyond this, a second wave could go further to tackle other structural bottlenecks. These challenges include reducing stringent regulation - particularly at the local level - and addressing corruption and weak enforcement of legal rights. The justice system is often slow and inefficient. And in the agricultural sector, strict land use restrictions and the structure of subsidies promote inefficiency. Moving even closer towards OECD best practices could increase potential growth by another percentage point annually.

This Working Paper relates to the 2015 OECD Economic Survey of Mexico (www.oecd.org/eco/surveys/economic-survey-mexico.htm).

JEL classification: D2, F1, H4, K4, L1, O4.

Keywords: economic growth, productivity, legal institutions, regulatory policies, structural reforms.

\section{Stimuler la croissance et réduire l'informalité au Mexique}

Le Mexique est engagé dans un ensemble audacieux de réformes structurelles qui lui permettront de rompre avec trois décennies de croissance lente et une faible productivité. Des mesures structurelles majeures ont été légiférées pour améliorer la concurrence, l'éducation, l'énergie, le secteur financier, le travail, les infrastructures et le système fiscal, parmi d'autres, et la mise en œuvre a commencé pour de bon. Si elles sont pleinement mises en œuvre, ces réformes pourraient augmenter la tendance annuelle de la croissance du PIB par habitant de près d'un point de pourcentage au cours des dix prochaines années, avec les réformes de l'énergie ayant les effets les plus importants. Au-delà, une deuxième vague pourrait aller plus loin pour s'attaquer à d'autres goulots d'étranglement structurels. Ces défis comprennent la réglementation stricte - en particulier au niveau local - et la lutte contre la corruption et la faible application des droits juridiques. Le système de justice est souvent lent et inefficace. Et dans le secteur agricole, des restrictions strictes d'utilisation des terres et la structure de subventions favorisent inefficacité. Aller encore plus vers les meilleures pratiques de l'OCDE pourrait augmenter la croissance potentielle d'un autre point de pourcentage par an.

Ce document de travail renvoie à l'Étude économique 2015 de l'OCDE sur le Mexique (www.oecd.org/fr/eco/etudes/etude-economique-mexique.htm).

Codes JEL : D2, F1, H4, K4, L1, O4.

Mots clés : croissance économique, productivité, cadre juridiques, politiques réglementaires, réformes structurelles 
TABLE OF CONTENTS

BOOSTING GROWTH AND REDUCING INFORMALITY IN MEXICO............................................

Improving regulation and addressing competition problems ..................................................................

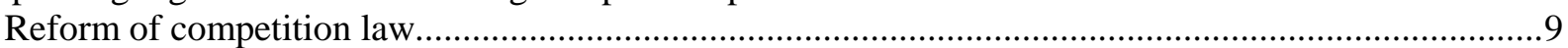

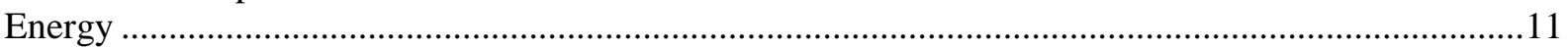

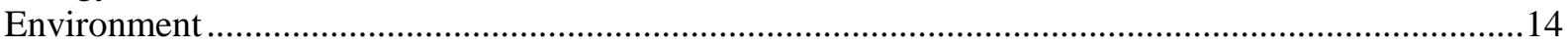

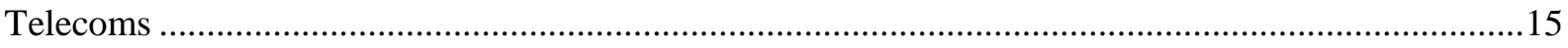

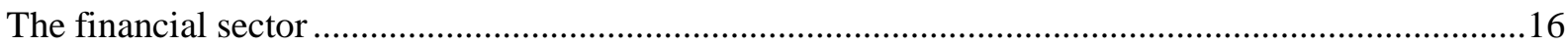

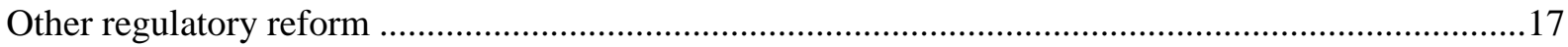

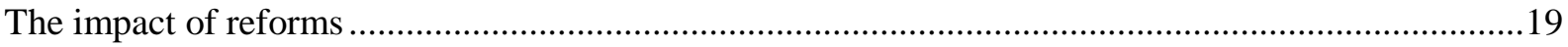

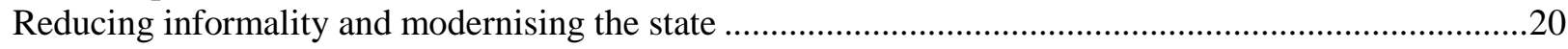

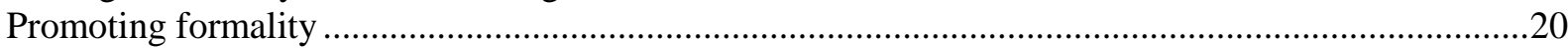

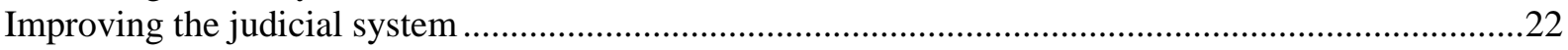

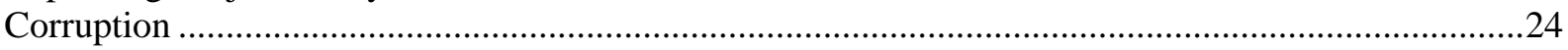

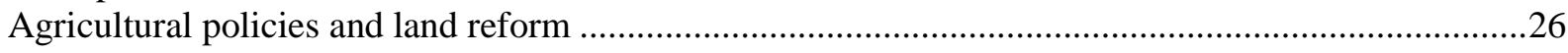

Strengthening the future conditions for moving up the value chain ........................................................28

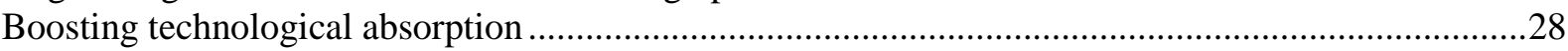

Creating an innovation and start-up friendly business climate .........................................................30

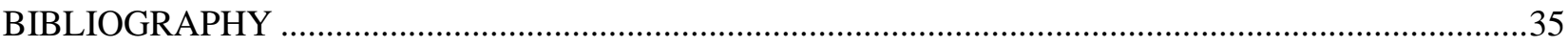

TECHNICAL ANNEX 1: STRUCTURAL REFORM PROGRESS ........................................................3

TECHNICAL ANNEX 2: REFORM IMPACT ASSUMPTIONS ………….............................................39

TECHNICAL ANNEX 3: PRODUCT MARKET REGULATION ……...................................................40

\section{Tables}

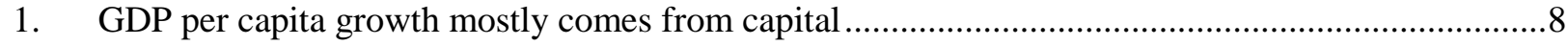

2. Mexico's prospective energy resources are considerable ..............................................................11

3. Regulatory stringency for electricity and gas sectors has been reduced..........................................12

4. Large reduction in product market regulation stringency for telecommunications ...........................15

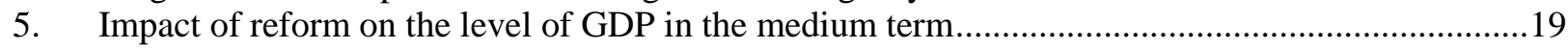

6. Gradual implementation of new system trials for criminal cases ...................................................24

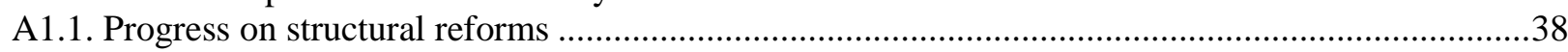

\section{Figures}

1. Trend growth of GDP per capita has been weak for three decades ................................................7

2. The percentage gap of GDP per capita and productivity are wide and persistent.............................7

3. The contribution of TFP to GDP growth has often been negative .................................................

4. Concentration was high in key economic sectors before the recent reforms ...................................9

5. Consumer welfare losses from competition problems are substantial and regressive ....................10

6. The stringency of sectoral product market regulation has been reduced ........................................13

7. There is a large gap in industrial electricity prices between Mexico and the United States.............14 


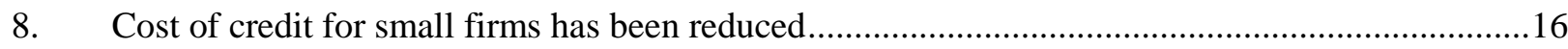

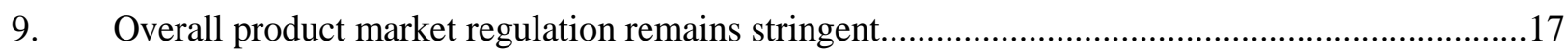

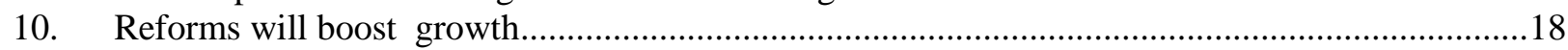

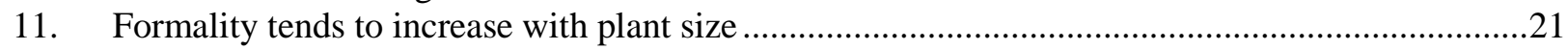

12. High informality rates are the most damaging for productivity....................................................22

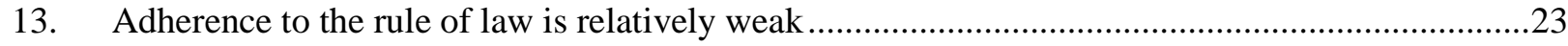

14. Mexico's public sector is perceived as corrupt ..............................................................................25

15. Producer support has declined and could be lower and less distortive ........................................27

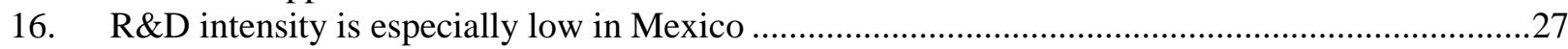

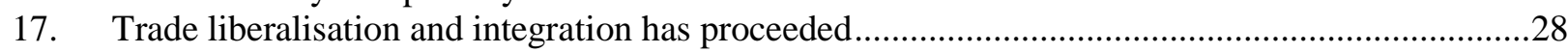

18. Services trade restrictiveness in telecoms has been reduced substantially ...................................29

19. Targeted policy tools to promote start-ups.....................................................................................31

20. The structure of Mexico's Productivity Commission..................................................................33

A3.1. Structure of the indicator of Product Market Regulation (PMR) ................................................42

\section{Boxes}

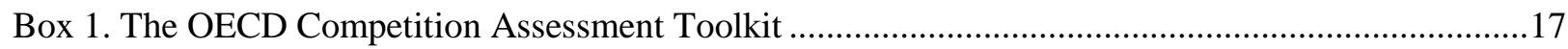

Box 2. Estimates of the GDP impact of structural reform ....................................................................18

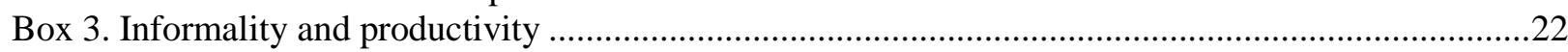

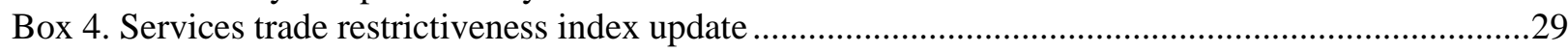

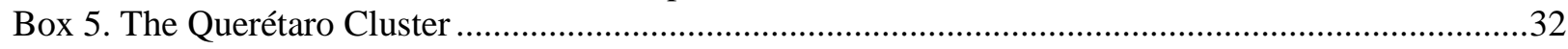

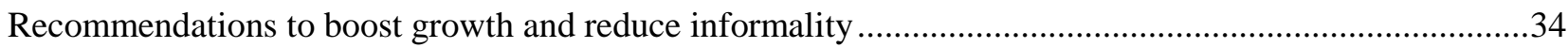




\title{
BOOSTING GROWTH AND REDUCING INFORMALITY IN MEXICO
}

\author{
By Sean M. Dougherty ${ }^{1}$
}

The Mexican economy is very open to world markets and hosts many modern firms, notably in the sectors of aerospace, automobiles, foods and drinks, which employ highly-skilled and well-educated workers. Nonetheless, this accounts for a relatively small part of the economy and is highly concentrated in a few regions. Other parts of the economy are characterized by high informality, low-skilled work, weak productivity levels and outdated technologies. In the informal sector, unregistered firms employ millions of workers lacking access to a good education, reliable health care and affordable financial services hampering their accumulation of human capital. A third segment of the Mexican economy consists of companies that, for decades, have been protected from competition - notably dominant firms in energy and telecommunications. These firms have been able to extract large rents from consumers and face low incentives to invest and improve productivity. Previous governments have sought to tackle these problems through a range of measures, but many of the reforms were not completed, and thus did not produce the hoped-for results.

Against this background, GDP per capita growth has been sluggish for three decades (Figure 1). The period prior to the 1980s was guided by unsustainable macroeconomic policies, which triggered a deep financial crisis in 1982, and was followed by a long downturn that only ended in 1989. Macroeconomic policies began to gain greater international credibility in the aftermath of the so-called "Tequila Crisis" in 1994, when Mexico also entered NAFTA. While Mexico has become more and more open to the global economy - broadening its trade exposure substantially beyond the United States - lack of sufficient economic reform hindered a higher trend growth of GDP per capita. Although recent reforms go a long way in addressing these challenges, follow-through and more reforms will be needed to build a truly "modern state" that levels the playing field, enforces competition laws, encourages doing business in the formal sector, promotes innovation, and looks after the well-being of all citizens.

1. Sean Dougherty is Senior Economist and Head of the Mexico Desk in the OECD Economics Department, contact email: Sean.Dougherty@oecd.org. This paper was prepared for the OECD Economic Survey of Mexico published in January 2015 (OECD, 2015a) under the authority of the OECD Economic and Development Review Committee. It was prepared with extensive input from Patrick Lenain. Contributions to the paper were made by Valery Dugain, Sean Ennis, Octavio Escobar, Natalia Fernández-Vázquez, Sandra Greiner, and Hildegun Nordås. Comments from EDRC committee members, numerous Mexican officials and OECD colleagues Bert Brys, Annamaria de Crescenzio, Agustin Diaz-Pines, Victor Duggan, Robert Ford, Jacobo Garcia Villarreal, Ana Llena Nozal, Carlo Menon, Natalia Nolan Flecha, Eduardo Olaberría, Álvaro Pereira, Mikaela Rambali, Gabriela Ramos, and Juan Yermo were greatly appreciated. Document preparation was expertly co-ordinated by Brigitte Beyeler and Nadia Kameleddine. 
Figure 1. Trend growth of GDP per capita has been weak for three decades

Annual growth rate

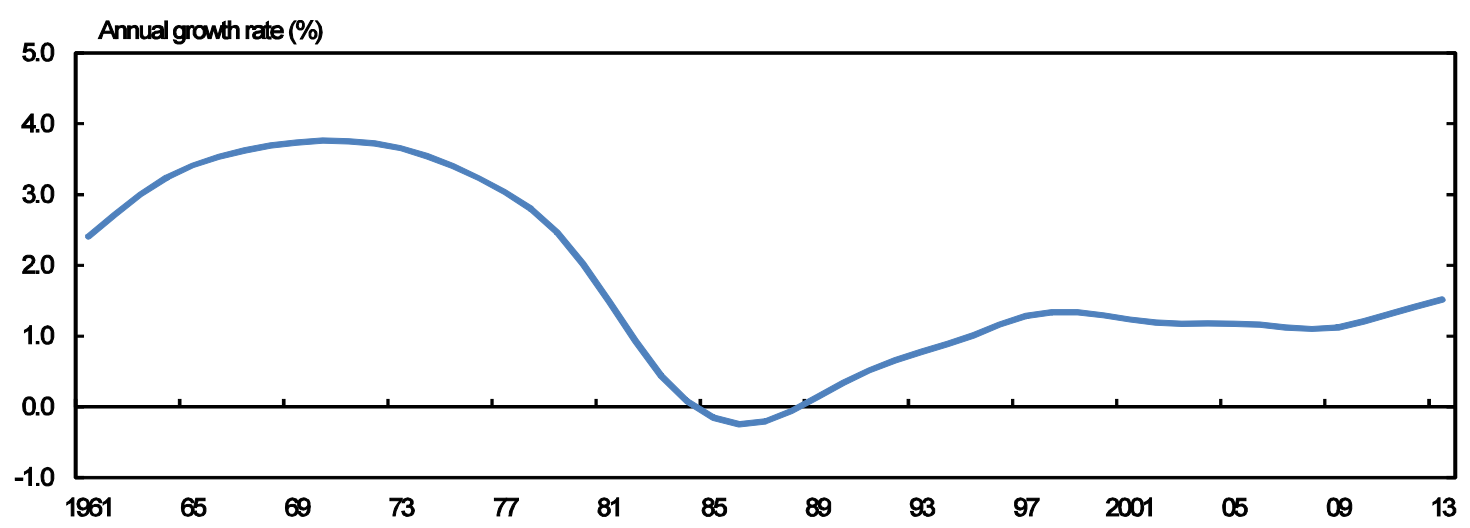

Note: Smoothed by a Hodrick-Prescott filter with a lambda of 100.

Source: OECD Analytical database.

Figure 2. The percentage gap of GDP per capita and productivity are wide and persistent

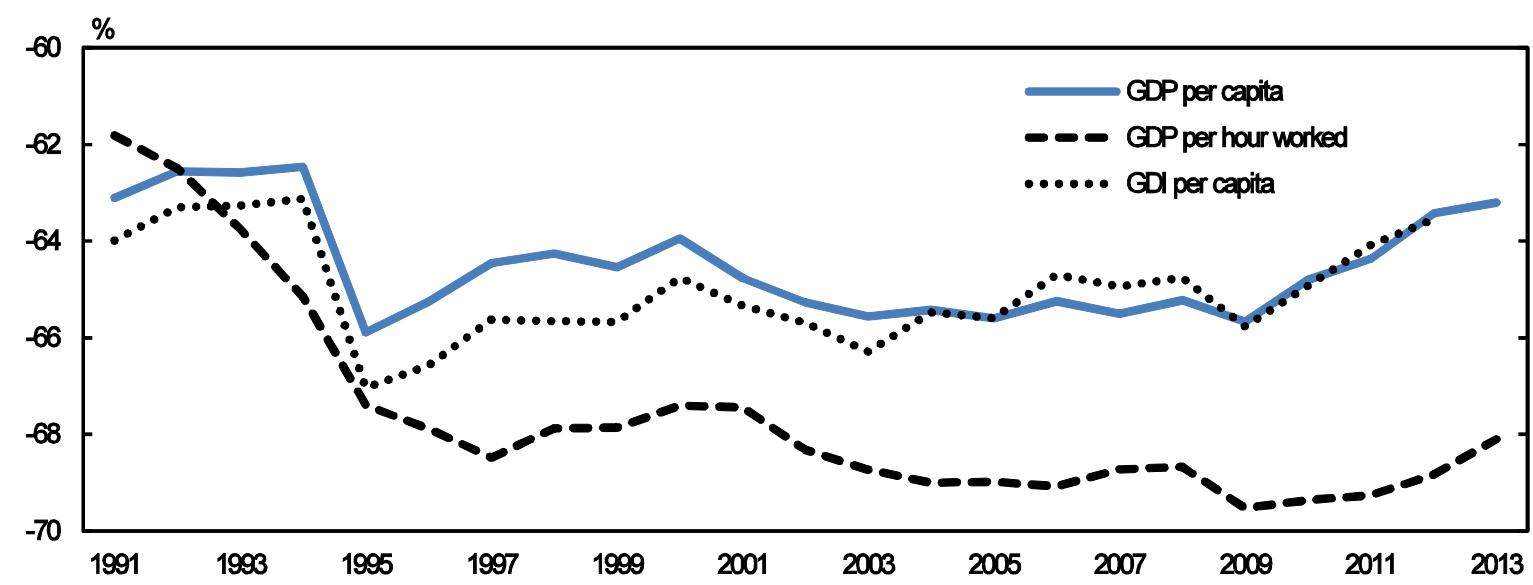

How to read this figure: Mexico's GDP per capita and per hour lags by more than $60 \%$ relative to the most advanced OECD countries.

Note: Percentage gap with respect to the simple average of the highest 17 OECD countries in terms of GDP per capita, GDP per hour worked and GDI per capita (in constant 2005 PPPs). Preliminary data for 2013.

Source: OECD (2015b), Going for Growth.

The central conundrum of Mexico's recent growth experience is that of low productivity (measured as GDP per hour worked) and slow convergence of incomes (Figure 2). Even setting aside crisis episodes, productivity growth has been weaker than what would be expected from a country that is far from the technological frontier. New results from the "KLEMS project" carried out in co-operation with the OECD show that the typical source of long-term GDP growth, total factor productivity (TFP), actually contributed negatively to growth (-0.4 per year) over the 1990-2011 period (Figure 3). Capital deepening was the most important and consistent source of growth, while increasing intensity of intermediate good use - notably through enhanced use of imported goods - was a close second contributor. An alternative decomposition of GDP per capita growth with an extended production function shows that human capital was a vital contributor as well, and once fully accounted for, implies that TFP was even lower (Table 1). 
Figure 3. The contribution of TFP to GDP growth has often been negative

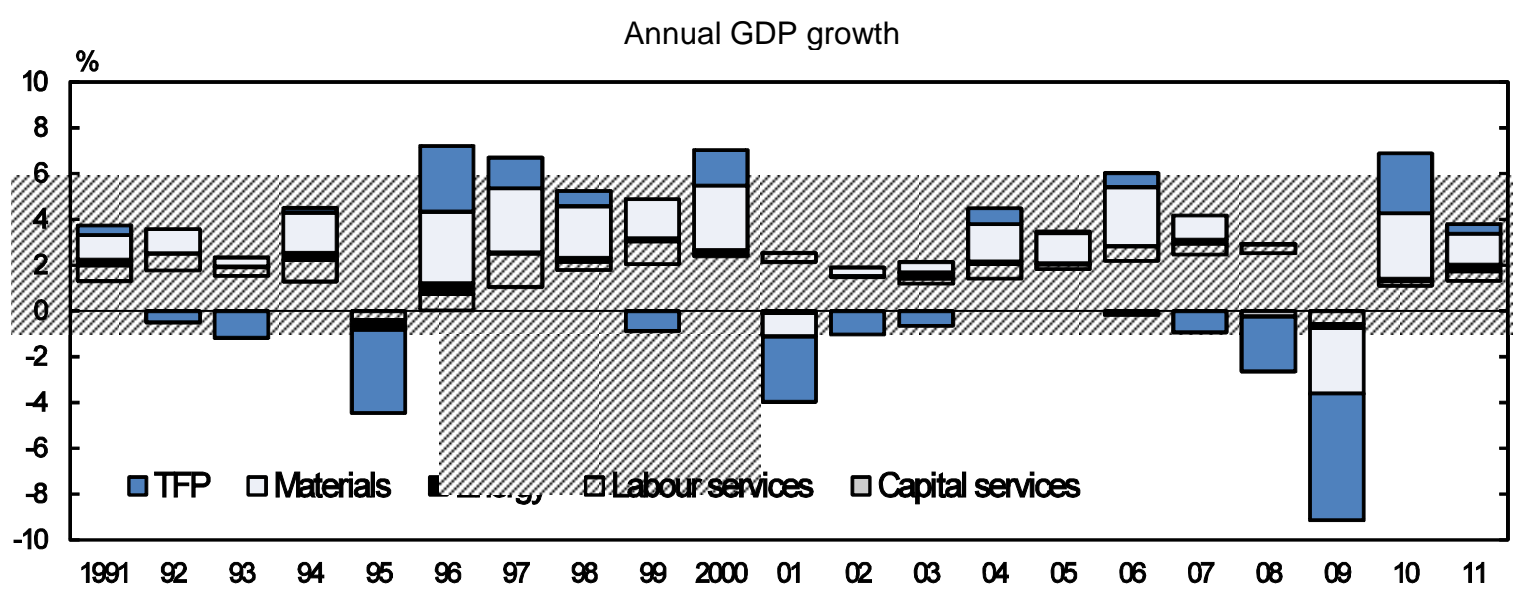

Notes: Based on a KLEMS decomposition of growth in value added, with total factor productivity (TFP) measured as the residual. Source: INEGI (2013).

Table 1. GDP per capita growth mostly comes from capital accumulation

\begin{tabular}{|c|c|c|}
\hline & $2002-07$ & $2007-12$ \\
\hline Potential GDP per capita & 0.4 & 0.5 \\
\hline Potential labour utilisation & -0.2 & -0.1 \\
\hline Potential labour productivity & 0.6 & 0.6 \\
\hline Human capital & 0.9 & 0.7 \\
\hline Physical capital intensity & 1.1 & 0.9 \\
\hline Labour efficiency (TFP) & -1.3 & -1.1 \\
\hline
\end{tabular}

Source: OECD (2015b), Going for Growth.

Mexico's slow productivity can be partly explained by the lack of sufficient reallocation of labour from low to high productivity sectors. Normally, in a developing economy, reallocation from low to high productivity sectors would contribute substantially to aggregate productivity growth. The main driver of intra-industry productivity growth has been manufacturing (Padilla-Pérez and Villarreal, 2014). However, in Mexico's case, productivity-enhancing reallocation has not occurred to a sufficient degree, as a large share of the reallocation of labour that has occurred has been towards low productivity services in the informal sector - yielding disappointing overall productivity outcomes. Moreover, episodes of strong productivity growth have been interrupted by frequent and severe economic downturns or crises, which suggest that there may have been insufficient resilience in the economy. However, the persistence of economic shocks in Mexico over the past 20 years is relatively low as compared with other OECD countries, suggesting that the problem for long-term growth outcomes is not so much a lack of macroeconomic resilience, but rather a sluggish trend (Sutherland and Holler, 2013).

Mexico has now embarked on a major reform program that was principally motivated by the slow growth and weak productivity of recent years (see Technical Annex 1). This chapter reviews key aspects of the reform programme, by examining each of the segments mentioned above. First, it examines the economy-wide and sectoral regulatory apparatus that promotes competition and the most recent structural reforms. Second, the challenge of informality is discussed, as well as its institutional drivers. And third, the environment that facilitates the most productive firms to emerge and prosper. Major reforms have been advanced in each of these areas, whose implementation will be critical to restart the catch-up process and boost productivity. Moreover, in each broad area further reforms could yield even more gains. 


\section{Improving regulation and addressing competition problems}

\section{Reform of competition law}

For decades, Mexico's economy has been hindered by a lack of product-market competition, with large firms becoming dominant players in several markets and earning large monopoly rents. To restore dynamism in these markets, between June 2013 and July 2014, the general competition agency COFECE has been strengthened and transformed into a constitutionally-autonomous body, with the power to remove "barriers to competition" and regulate access to "essential facilities", similar to the UK competition authorities. Criminal penalties for hard-core cartels, including bid-rigging, have also been increased. This should help to address competition problems in the substantial number of markets that have high concentration of incumbent operators, where concentration ratios had been present for various reasons prior to the reforms (Figure 4). Given its expanded mandate, he competition agency's budget has been increased by about 50\%, though it remains relatively small in budgetary and headcount terms.

Figure 4. Concentration was high in key economic sectors before the recent reforms

Herfindahl-Hirschmann Index (HHI), 2010

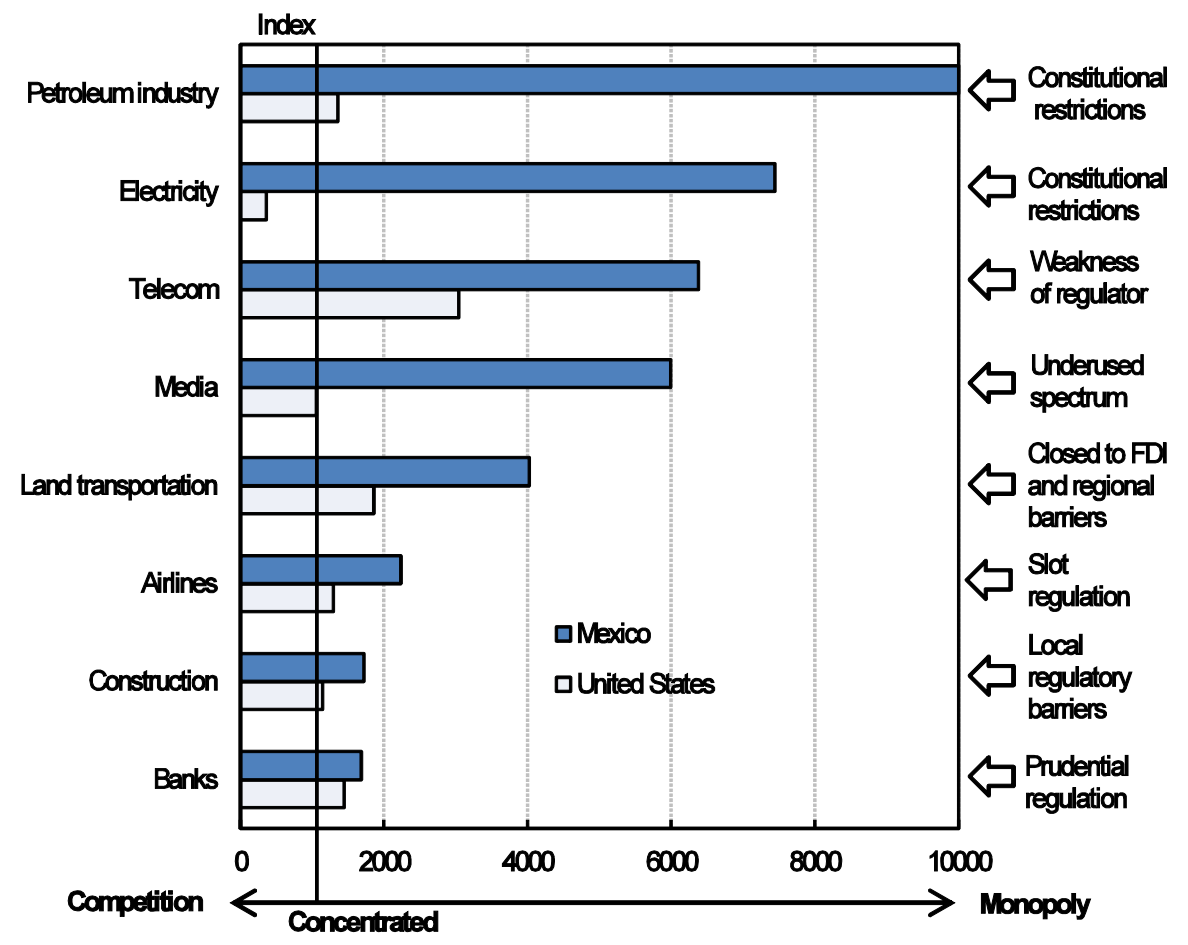

1. The $\mathrm{HHI}$ index is measured on a scale of 0 (most competitive) to 10000 (least competitive) based on the sum of the squared market shares of firms in a sector. The US Department of Justice considers sectors with an HHI between 1500 and 2500 to be moderately concentrated and over 2500 as highly concentrated.

Source: CIDAC (2011).

A number of non-controversial changes have been made, including amending the bid rigging provision to include any bid procedure not just public procurement; making exchange of information for purposes of collusion a per se offence; adding "margin squeeze" to the list of monopolistic practices; and, adding an ability to seek info from third parties and public bodies in the context of merger reviews and allowing a longer timeframe for those reviews. These changes alone have added valuable tools to the competition law arsenal in Mexico. 
The introduction of the competition authority's ability to prevent or remove "barriers to competition" has been somewhat controversial. While the statute specifies that actions should be in "necessary proportions to eliminate the anticompetitive effects", they include breaking up companies through divestitures. However, there may be good policy justifications for the Mexican authorities to have this as a tool of last resort, given broader institutional weaknesses (Ennis et al., 2014). Previous OECD reviews have noted that problematic circumstances can arise from concentrated industries in Mexico - particularly those created following privatisation of state monopolies - as well as those protected from import competition, but for which no evidence of unlawful monopolistic practices can be found.

A second notable change to the competition law is the introduction of a power to regulate access to essential inputs, in a manner closely related to the "essential facilities" doctrine. This doctrine refers to situations where an entity controlling an essential input (or network, facility, etc.) also participates in the downstream market that relies on that input, and can leverage its control of the essential input by raising prices or foreclosing downstream rivals, to the ultimate detriment of competition in the downstream market. The new provisions favour commercial activity, by enhancing the competition authorities' ability to conduct investigations and stop restrictive business practices, thus making it easier for new businesses.

Important progress has been made in establishing specialised economic courts. In 2013, two new competition and telecommunications specialised courts as well as two tribunals in such matters were established. These are based in Mexico City but have nation-wide jurisdiction. The current judges were elected by the Federal Judiciary Council (FJC) based on their expertise on such matters. Moreover, further efforts are currently underway, in a joint work with the Competition Regulator (COFECE), to train specialized judges in telecommunication and competition analysis. As of mid-2014, these District Courts have handled more than 30 trials directly related to anticompetitive conduct. The introduction of specialized courts has been a key variable in improving the economic competition policy in Mexico.

Empirical evidence from the National Household Income and Expenditure Survey covering seven goods industries shows that social losses due to market power in Mexico are not only large and significant, but also very regressive. The lowest income decile is $25 \%$ more affected than the top income decile. The loss in social welfare is most acute for the rural population (Figure 5). Enhancing competition would increase the purchasing power of consumers and ease income inequality.

Figure 5. Consumer welfare losses from competition problems are substantial and regressive Per cent of additional losses ${ }^{1}$ per household's decile relative to the top decile

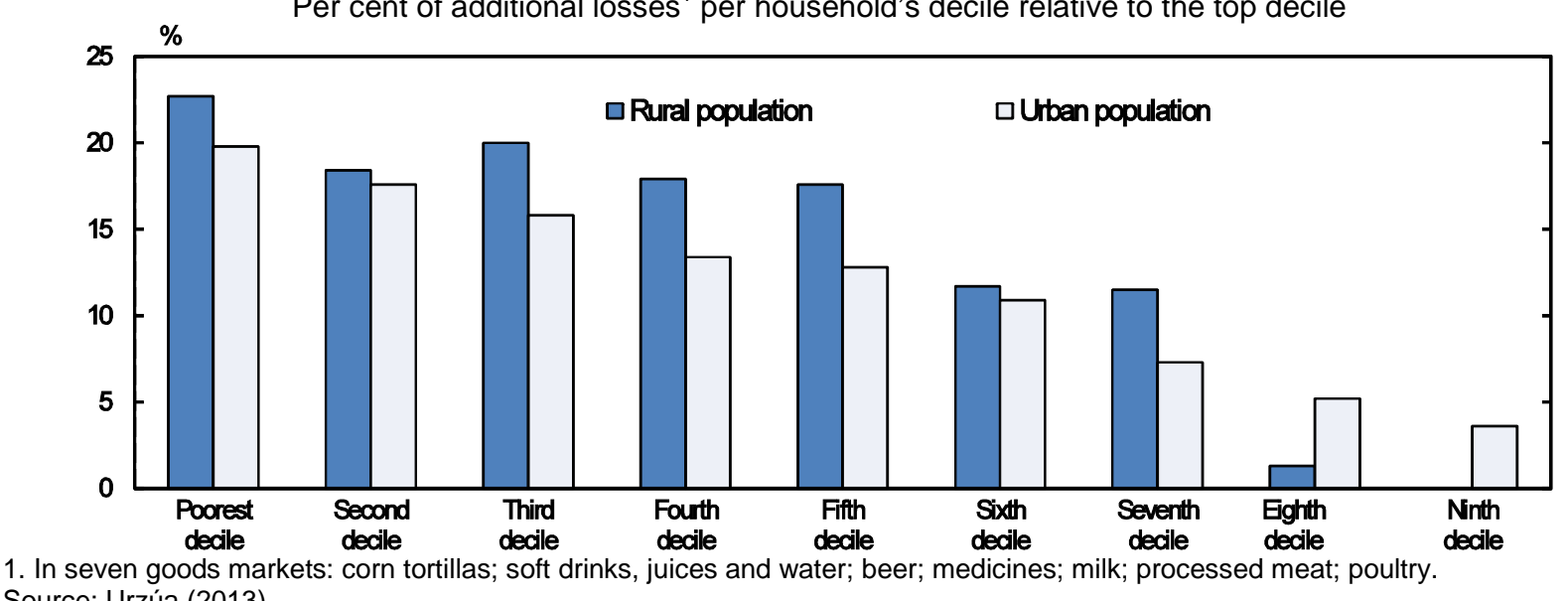
Source: Urzúa (2013).

The energy and telecom sectors have already been opened to greater competition, with economy-wide effects. These reforms can be observed through changes in the stringency of product market regulation (PMR), using OECD indicators. An interim update of these indicators through August 2014 shows that 
Mexico has eased its regulatory stance from one of the most stringent levels (see below), though there is still considerable scope for improvement. Sector-specific indicators show more progress, notably in telecoms, where Mexico beats the OECD average. Two-thirds of these indicators' value reflects legislative changes in regulation, but de facto contestability of the market is also measured through the market share of either the incumbent or new entrants, and by this measure, it will take some time for the reforms to have their full impact on competition.

\section{Energy}

Mexico has launched a major reform of the oil and gas sectors, following years of declining oil production by the state-owned company PEMEX, high energy costs for the business sector, and a lack of funding and technology to exploit new energy resources. Congress passed 21 pieces of secondary legislation in August 2014 to implement a constitutional reform approved in late 2013. These laws established several largely autonomous, independently-funded regulators for the licensing, safety and environmental protection of the sector. These new regulators will help supervise the opening of the sector to greater competition and more efficient use of national resource wealth. In addition, the governance of PEMEX is being reformed, with a Board that for the first time will comprise independent directors responsible for establishing the company's strategic vision of the company supported by committees, and it will no longer play the role of "gate-keeper" to the energy sector. Mexico now allows the entry of both domestic and foreign investors in the exploration, production and transportation of oil and gas, as well as the refining and marketing of hydrocarbons, potentially attracting considerable new investment, especially for prospective reserves where much larger initial investments and more advanced expertise is required (Table 2). These changes are estimated by market observers to likely boost long-term petroleum output by $75 \%$ annually relative to the baseline case (USIEO, 2014).

Table 2. Mexico's prospective energy resources are considerable

MMMboe (billion barrels of oil equivalent), January 2014

\begin{tabular}{lllllll}
\hline & & \multicolumn{3}{c}{ Reserves } & \multicolumn{2}{c}{$\begin{array}{c}\text { Prospective } \\
\text { Resources }\end{array}$} \\
\cline { 3 - 7 } Basin & $\begin{array}{l}\text { Cum. } \\
\text { Prod. }\end{array}$ & $\begin{array}{l}\text { 1P (90\%) } \\
\text { Development and Exploitation } \\
\text { Projects }\end{array}$ & $\begin{array}{l}\text { 2P (50\%) } \\
\text { 3P (10\%) }\end{array}$ & $\begin{array}{l}\text { Conv. } \\
\text { Exploration Projects }\end{array}$ \\
\hline Southeastern & 46.5 & 11.8 & 17 & 23.4 & 16.8 & \\
Tampico Mislanta & 6.5 & 1.1 & 6.6 & 15.7 & 2.4 & 34.8 \\
\hline Burgos & 2.4 & 0.3 & 0.5 & 0.7 & 3 & 10.8 \\
Veracruz & 0.8 & 0.2 & 0.2 & 0.3 & 1.4 & 0.6 \\
\hline Sabinas & 0.1 & 0 & 0 & 0.1 & 0.4 & 14 \\
Deepwater & 0 & 0.1 & 0.4 & 2 & 27.1 & \\
Yucatán Platform & & & & & 1.5 & \\
Total & $\mathbf{5 6 . 2}$ & $\mathbf{1 3 . 4}$ & $\mathbf{2 4 . 8}$ & $\mathbf{4 2 . 2}$ & $\mathbf{5 2 . 6}$ & $\mathbf{6 0 . 2}$ \\
\hline
\end{tabular}

Note: "1P reserves" = proven reserves $(90 \%)$; "2P reserves" = proven + probable reserves $(50 \%)$; "3P reserves" = proven + probable+ possible reserves $(10 \%)$. Prospective reserves include non-conventional resources that require special processing, such as shale oil.

Source: PEMEX.

The energy reform follows recommendations made in previous OECD Economic Surveys (OECD, 2013a), and allows for a range of modalities of private sector involvement, including profitsharing, production-sharing and licensing arrangements. Downstream - including midstream, refining and distribution activities - will be open to full private sector competition, including for imports of oil and natural gas, supervised by a dedicated regulator (CRE) and the Ministry of Energy. For Upstream, contractual terms will be set primarily by the Ministry of Finance and the Ministry of Energy, while the 
upstream regulator $(\mathrm{CNH})$ will administer the contracts. Contracts will be awarded through international public tenders, using an economic bidding variable so that the overall fiscal terms will be determined through market mechanisms. An overall national content requirement will begin at $25 \%$ in 2015 and rise to a share of 35\% by 2025 (excluding deep-water), which is comparable to a number of other emerging markets. It will be important to ensure that the new contracting rules, including for local content, for oil and gas investment are carefully designed in order to ensure they are sufficiently attractive, yet also create a competitive market for large-scale private sector participation.

A two-stage process has been followed to determine process has been followed to determine the areas that will be grandfathered to PEMEX and the areas that will be available for bidding rounds. Through a "Round Zero" process, which has already concluded, PEMEX was granted $100 \%$ of what it requested in the so-called "2P Reserves", which is to say the equivalent to $83 \%$ of all of such $2 \mathrm{P}$ Reserves of the country, which represent resources for approximately 20.6 billion barrels of crude petroleum. Furthermore, PEMEX was granted 21\% of the prospective resources of Mexico, the equivalent of 22.1 billion barrels of crude, $67 \%$ of what PEMEX requested. The majority of the resources that were granted to Pemex are concentrated in shallow water deposits, while in deep water, where the oil company has limited experience, fewer fields were granted to it. In the case of deep water, $42 \%$ of the prospective resources were granted to it. Starting in November, preliminary terms of the "Round One" bidding process will be established, and the Ministries of Energy and Finance will begin to provide the details of the fiscal and contracting model for various fields. Bidding will begin in spring 2015. The government expects that with these open bids will attract USD 50 billion dollars of investment between 2015 and 2018.

The electricity sector has also been liberalised, by ending the monopoly of the state-run power utility CFE and by promoting competition from new entrants. OECD indicators of product market regulation updated for this Survey were used to score the new framework (see Technical Annex 3). These indicate a reduction in the indicator of about $1 / 3$ in the sectoral indicators for electricity and gas (Figure 6, Panels A and B; Table 3). These changes are mainly driven by changes in the entry regulation and vertical integration indicators. Energy reforms now make it legally possible for private firms to fully intervene in the generation and marketing of electricity and to compete in the transmission and distribution activities through contractual agreements. The Energy Regulatory Commission (CRE) has the legal responsibility of granting electricity generation permits. The energy reform creates an Independent System Operator (National Energy Control Centre) that ensures legal compliance by transmission and distribution firms interacting with Federal Electricity Commission. In addition, the degree of separation in the value chain of the electricity sector changed from the most stringent level to a legal separation status.

Table 3. Regulatory stringency for electricity and gas sectors has been reduced

\begin{tabular}{|c|c|c|c|c|c|c|c|c|c|c|}
\hline \multirow[b]{2}{*}{ Year } & \multicolumn{5}{|c|}{ Electricity } & \multicolumn{5}{|c|}{ Gas } \\
\hline & Entry & $\begin{array}{l}\text { Public } \\
\text { ownership }\end{array}$ & $\begin{array}{l}\text { Vertical } \\
\text { integration }\end{array}$ & $\begin{array}{l}\text { Market } \\
\text { structure }\end{array}$ & Overall & Entry & $\begin{array}{l}\text { Public } \\
\text { ownership }\end{array}$ & $\begin{array}{l}\text { Vertical } \\
\text { integration }\end{array}$ & $\begin{array}{l}\text { Market } \\
\text { structure }\end{array}$ & Overall \\
\hline 1998 & 6 & 6 & 6 & 6 & 6 & 4.0 & 4.5 & 5.25 & 6 & 4.94 \\
\hline 2003 & 6 & 6 & 6 & 6 & 6 & 3.5 & 4.5 & 5.25 & 6 & 4.81 \\
\hline 2008 & 6 & 6 & 6 & 6 & 6 & 3.5 & 4.5 & 5.25 & 6 & 4.81 \\
\hline 2013 & 6 & 6 & 6 & 5.25 & 5.81 & 3.5 & 4.5 & 3 & 6 & 4.25 \\
\hline 2014 & 2 & 6 & 3 & 5 & 4 & 0 & 4.5 & 3 & 3 & 2.63 \\
\hline
\end{tabular}

Note: Stringency of OECD product market regulation ranges from 6 (most stringent) to 0 (least stringent).

Source: OECD Product Market Regulation database, 2014 and interim estimates prepared in co-operation with Mexican authorities.

Expanded availability of shale gas in particular, and the more competitive framework for electricity, is likely to trigger a fall in electricity and gas prices once new gas pipelines are completed, narrowing the substantial gap with the United States, and thus making energy-intensive manufacturing sectors more 
competitive (Figure 7). Although the largest economic effects of the reforms are likely to be realized only in the medium and long term, energy reform will be among the most front-loaded, since the investments may happen in the relatively short term.

Figure 6. The stringency of sectoral product market regulation has been reduced Index scale of 0-6 from least to most restrictive (January 2013)
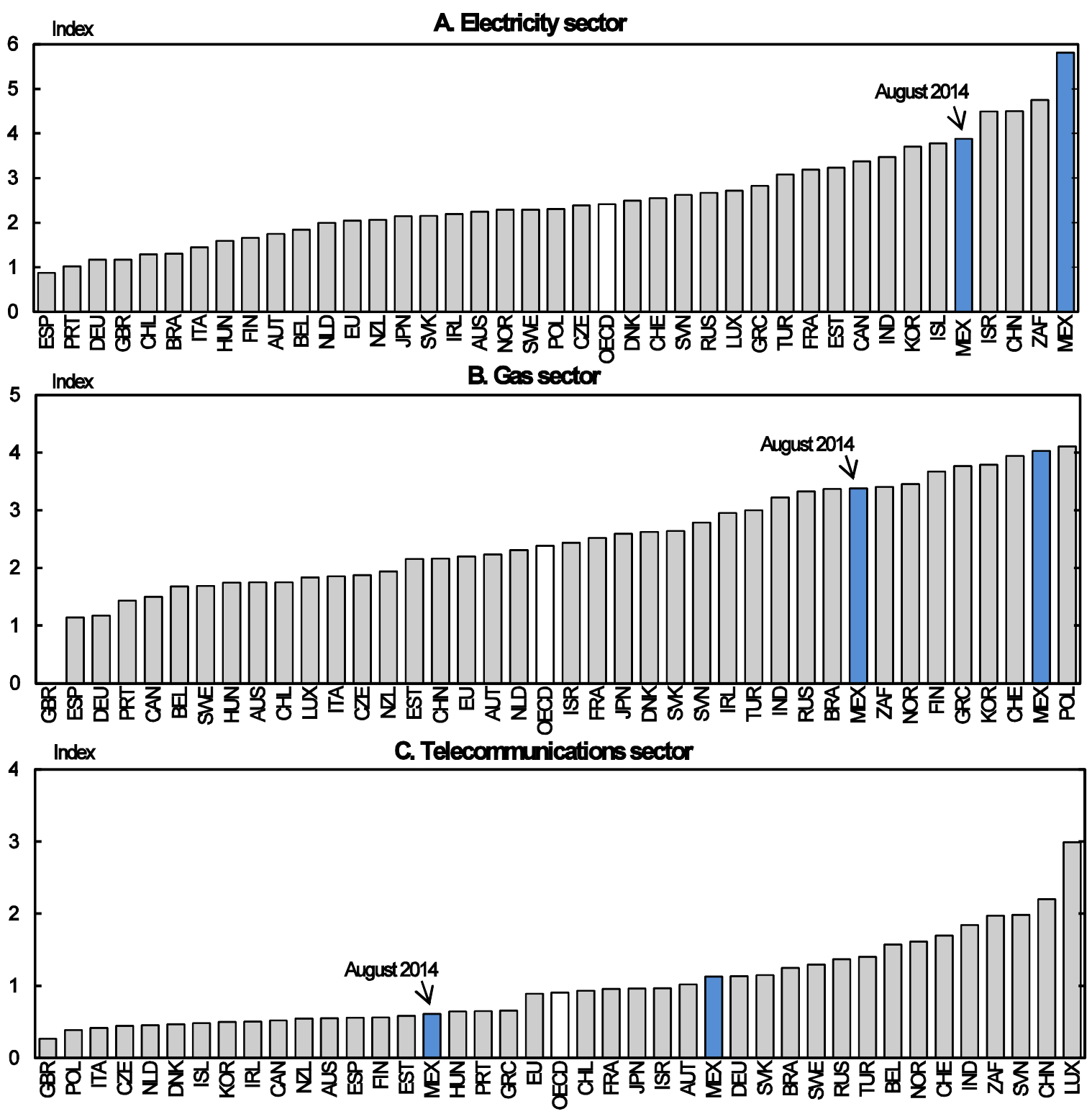

How to read this figure: Mexico's regulation in the three network sectors mentioned above became substantially less restrictive from January 2013 to August 2014, moving towards the OECD average, or below it in the case of telecoms.

Source: OECD Product Market Regulation database, 2014 and interim estimates prepared in co-operation with Mexican authorities. 
Figure 7. There is a large gap in industrial electricity prices between Mexico and the United States

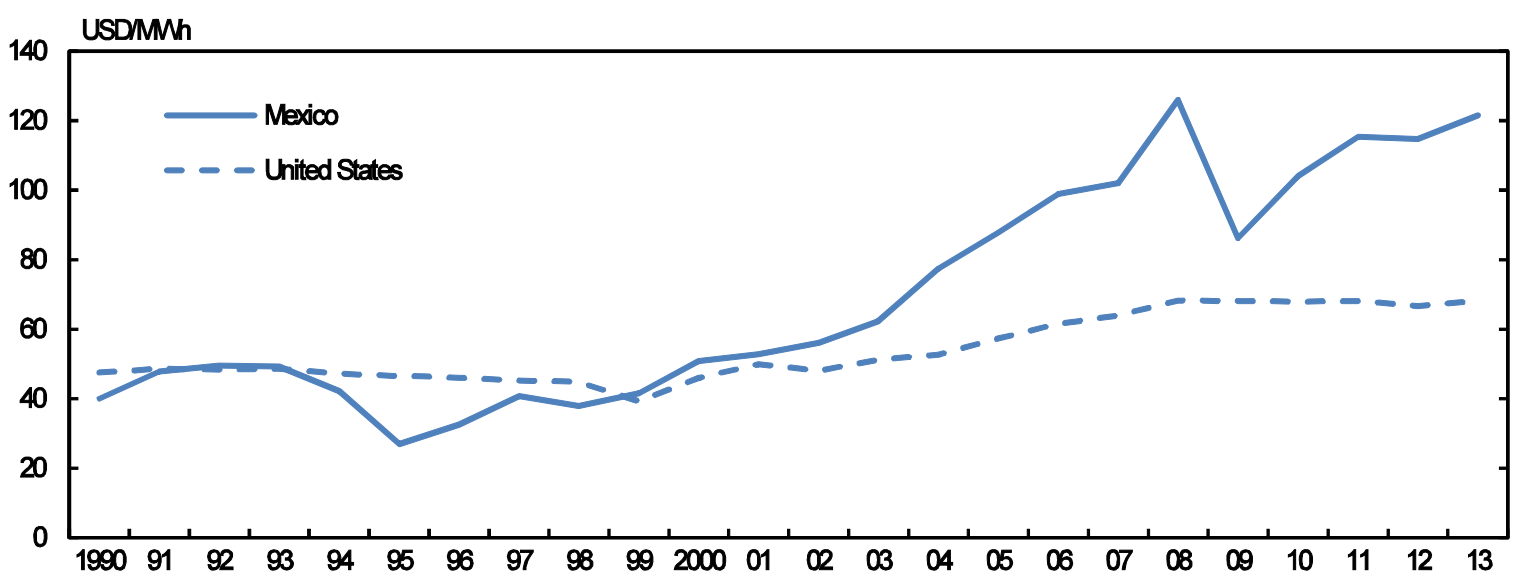

Source: International Energy Agency via OECD.Stat.

\section{Environment}

Until recently Mexico extended large budgetary support for fossil fuels and was the only country in the OECD with negative income from environmental taxes. This can mainly be attributed to the variable tax component of the Excise Tax on Products and Services on Gasoline and Diesel. The excise tax turned into a subsidy when international oil market prices were high and the government compensated Pemex for the difference arising from lower domestic sales prices of gasoline and diesel set by the government. The subsidy on gasoline is expected to disappear by the end of 2014 and to have a positive collection of excise tax on fuel from 2015 onwards.

$\mathrm{CO}_{2}$ emissions in Mexico have been growing considerably over the past two decades, rising about one-third from 1990 in 2010 (to $748.3 \mathrm{Mt} \mathrm{CO}_{2}$ ). The largest contributors of emissions are energy and transport, followed by waste. At the same time, the share of renewable energy in total primary energy supply has declined from $12 \%$ to $9 \%$. However, the emission intensity of the electric grid has slightly decreased owing to the substitution of oil by gas. Recent reforms include specific provisions geared towards eliminating barriers to renewable energy, as well as providing for the use of green certificates and the adoption of specific legislation on the promotion of geothermal energy. The recent tax reform preserved the allowance for accelerated deduction of investments on energy generation with renewable sources.

The liberalisation of the energy market should help in reducing greenhouse gas emissions in the sector, as it will help make carbon pricing more responsive to price signals. As part of the energy sector reforms, Mexico also adopted an Excise Tax (IEPS) on carbon emissions. The tax is determined by the carbon content of fossil fuels and applies to producers, manufacturers and importers of fuels. With a rate of 3.2 USD per tonne of $\mathrm{CO}_{2}$ (natural gas and jet fuel are excluded), the tax is unlikely to have a major impact in the short run but is expected to gradually increase over time.

Mexico has strengthened its political commitment to reduce greenhouse gas emissions by $30 \%$ in 2020 (with respect to the business as usual scenario) provided adequate financial and technological support from developed countries is sufficient. For this purpose, a carbon tax on fossil fuels has been introduced in 2014. In addition, the retail price of gasoline and diesel will be raised, until 2017, in line with overall inflation. Based on current oil prices, this is expected to eliminate the fossil fuel subsidy that has prevailed at a high level in recent years, and result in gasoline and diesel products being effectively taxed; further action would be needed if oil prices were to rise significantly from current levels. Beginning in 2018, 
gasoline prices will be liberalised and determined by market conditions. Despite these initiatives and targets, reducing greenhouse gas emissions remains a major challenge for Mexico. Although carbon emissions per capita are low, the energy and carbon-intensity of the economy is high compared to other OECD countries. Therefore, establishing adequate prices, removing inefficient subsidies (and providing better targeted support to the poor), and improving energy efficiency will all be needed if Mexico is to meet its greenhouse gas emissions target. The new effective carbon tax should be evaluated, and raised if deemed inadequate.

\section{Telecoms}

A new regulatory and competition agency (IFT) focused on telecommunications and broadcasting was formed in 2013 and following the passage of the secondary legislation in May 2014, it is now fully operational. The IFT has exclusive authority for regulation and competition enforcement in the telecommunications and media industries, and has a range of new regulatory capabilities to promote competition, such as imposing obligations on dominant operators. The dominant operator in the fixed-line market Telmex has an $80 \%$ market share, while the mobile company Telcel has a 70\% market share. OECD studies have suggested that data prices are relatively high (OECD, 2012a). An initial decision requiring these companies' owner, América Móvil, to provide free interconnection to other operators, triggered its announcement of a plan to sell assets to reduce its market share below the $50 \%$ regulatory threshold to avoid the application of asymmetric regulations. The response suggests that the new framework is having an impact, though attention will need to be paid as to whether a smaller market share still ensures adequate market competition from a customer perspective. A full-fledged competition assessment may still be required to ensure that individual market segments do not face market dominance. In addition, given the rapid technological developments in the telecommunications sector, close monitoring of the technological evolution and boundaries of the sector will also be required. There is also an outstanding international compliance issue regarding the conditionality of market access rules to FDI in the telecoms sector - these appear to be contrary to OECD investment instruments and other international conventions that prohibit reciprocity. These will need to be addressed in order to avoid future legal complications.

According to the OECD's regulatory restrictiveness indicators for the sector (Table 4; Figure 6, Panel C), Mexico's regulatory stance for telecommunications has now been relaxed by a very large margin, about $46 \%$ of the value of the previous value of the indicator. This is mainly driven by a shift in the entry conditions, which have been affected by the introduction of a stronger regulator and strengthening of the legal system which end a period where there were few barriers to a monopoly in the sector. Cross-country studies using these indicators imply that such reforms could have large positive effects on productivity growth that could help to accelerate the convergence process (Bourlès et al., 2013).

Table 4. Large reduction in product market regulation stringency for telecommunications

\begin{tabular}{lcccc}
\hline & \multicolumn{4}{c}{ Telecom } \\
\cline { 2 - 5 } Year & Entry & $\begin{array}{c}\text { Public } \\
\text { ownership }\end{array}$ & $\begin{array}{c}\text { Vertical } \\
\text { integration }\end{array}$ & Overall \\
\hline $\mathbf{1 9 9 8}$ & 2.25 & 0 & 2.94 & 1.73 \\
$\mathbf{2 0 0 3}$ & 1.5 & 0 & 2.08 & 1.19 \\
$\mathbf{2 0 0 8}$ & 1.5 & 0 & 2.23 & 1.24 \\
$\mathbf{2 0 1 3}$ & 1.5 & 0 & 1.88 & 1.13 \\
$\mathbf{2 0 1 4}$ & 0 & 0 & 1.84 & 0.61 \\
\hline
\end{tabular}

Notes: Stringency of OECD product market regulation ranges from 6 (most stringent) to 0 (least stringent).

Source: OECD Product Market Regulation database, 2014 and interim estimates prepared in co-operation with Mexican authorities. 


\section{The financial sector}

Mexico is underbanked compared to other OECD economies. Large segments of the population do not use formal banking services, and much progress needs to be made to promote financial inclusion and to increase the use of banking services. Financial sector concentration and lack of financial market depth have been a longstanding problem in Mexico. Such problems not only reduce productivity in the financial sector, but also limit the role that consumption and investment smoothing can have in tempering macroeconomic volatility. The empirical evidence suggests that there does not need to be a trade-off between the growth-enhancing effects of deeper financial markets and higher macroeconomic stability (Sutherland and Hoeller, 2013).

Concerns about the high cost of credit and lack of competition in the banking sector have motivated a major financial reform. Legislation passed in January 2014 strengthening regulation, increases competition and lowers the cost of borrowing. These changes should allow for more robust and sustainable private credit deepening, the penetration of which is currently far below the OECD average. Large segments of the population do not use formal banking services, and there is much progress still to be made to promote financial inclusion and increasing banking penetration.

Three sets of measures stand out in the reform: more effective property-rights protection for creditors, more formal legal authority for the regulator to manage the resolution of banks, and the promotion of competition among financial intermediaries. The reform reduces obstacles in the judicial process to recovering collateral, following longstanding difficulties in enforcing creditors' property rights. More immediately, government development banks have been given more scope for lending to small and medium-size businesses (SMEs), which often lack access to credit. The latter measure already appears to have borne fruit in driving down interest rates for SMEs, including those without support (Figure 8).

Figure 8. Cost of credit for small firms has been reduced

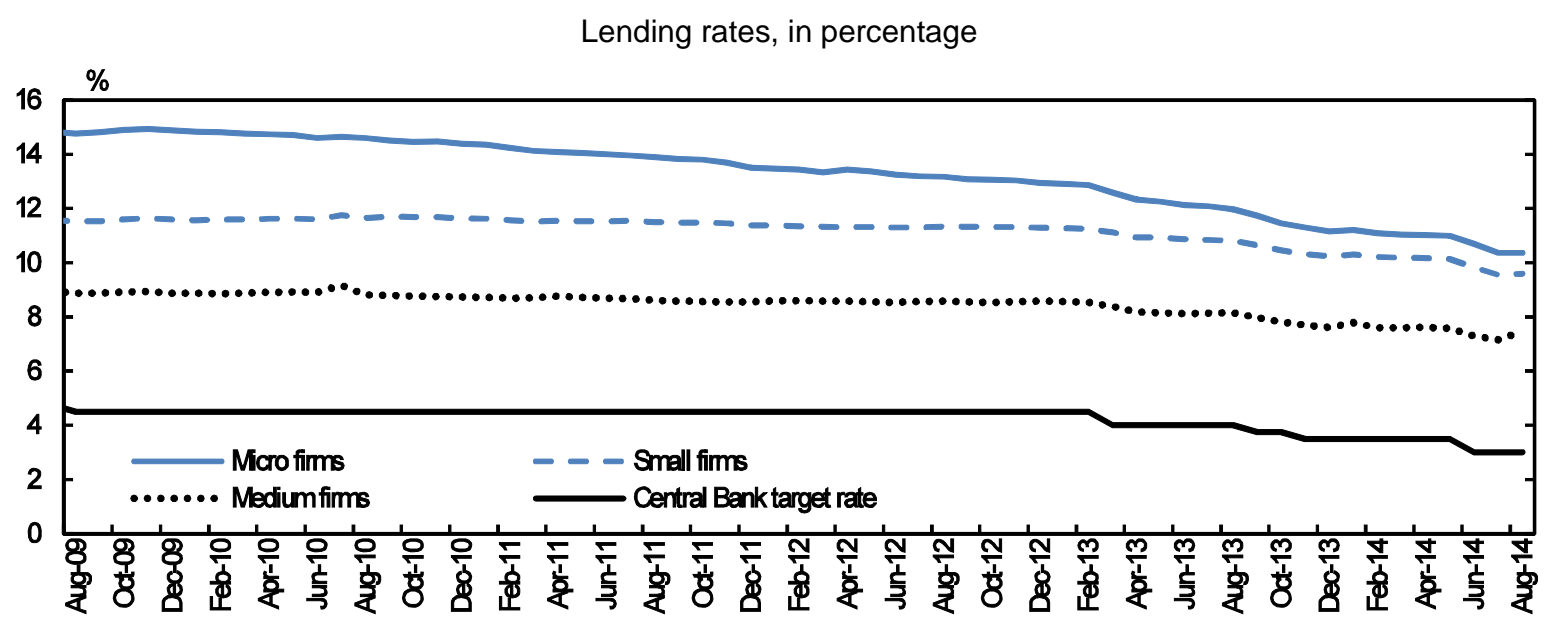

Note: Market interest rates for various types of borrowers.

Source: CNBV.

As part of the changes, brought about by the financial reform, the Federal Economic Competition Commission was instructed to report competition conditions in the financial sector. The findings were made public in July 2014 and, now represent the main issues on which current efforts are being focused. These measures complement rule changes already made, such as those regarding competition and transparency in payment system networks eliminating entry barriers for new participants in the market. Recommendations include access to ATMs on a non-discriminatory basis, and with charges based on long 
term incremental costs, as well as to regulate exchange fees for credit and debit cards, in order to foster the use of these payment systems.

\section{Other regulatory reform}

Dynamism is still hampered by stringent regulations in many markets. The government aims to lighten the regulatory burden with constitutional reforms and secondary legislation. There is still a large stock of administrative regulations in many domains, notably in business entry and operation at the state and local levels, such as can be seen in the Sub-national Doing Business indicators (World Bank, 2014). Moreover, while sectoral regulation has been reduced substantially, the effect of these reforms on the overall OECD PMR index is not substantial, partially because the market share of dominant firms remains similar to before (Figure 9). Once the sectoral reforms start to take full effects, these sub-indicators are likely to evolve further.

Figure 9. Overall product market regulation remains stringent

Index scale of 0-6 from least to most restrictive

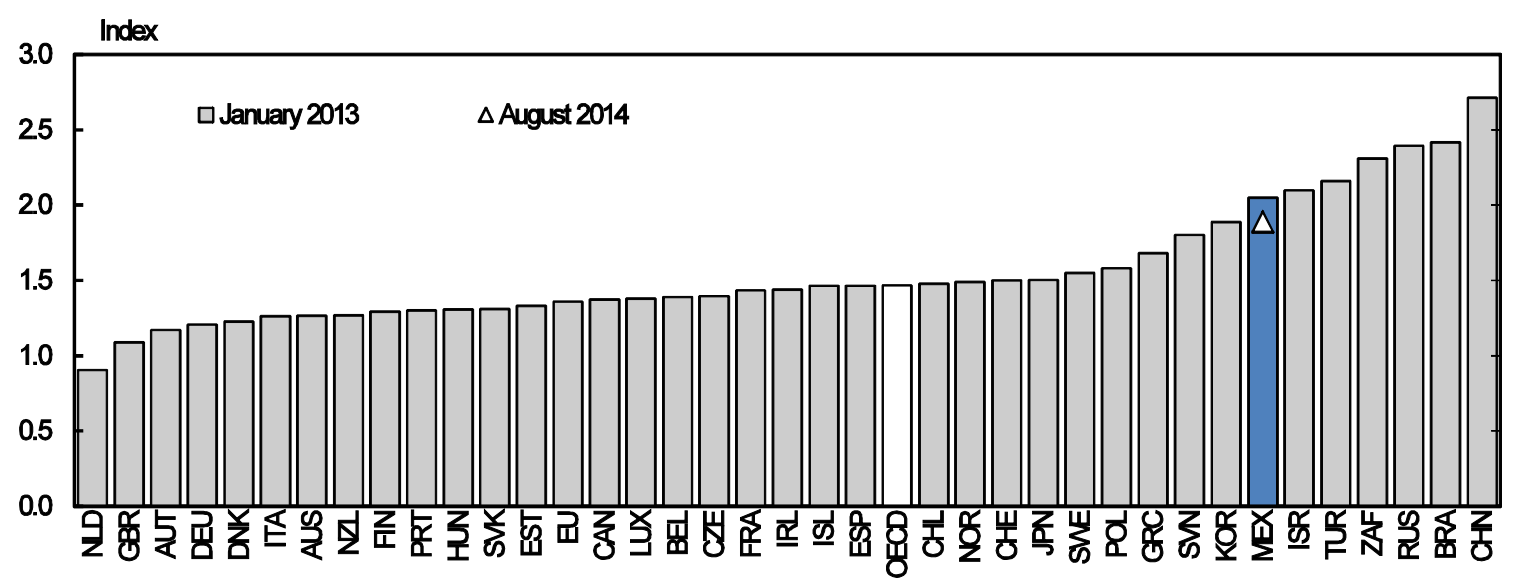

Source: OECD Product Market Regulation database, 2014 and interim estimates prepared in co-operation with Mexican authorities.

\section{Box 1. The OECD Competition Assessment Toolkit}

The Toolkit contains a checklist that signals when there is a potential competition problem that should be investigated in more depth, along the lines of those regularly conducted by Competition Authorities. The checklist identifies potential problems if the policy, law or regulation will:

- $\quad$ Limit the number or range of suppliers, e.g. establishes a license process as an operation requirement

- Limit the ability of suppliers to compete, e.g. significantly raises production costs of new entrants relative to incumbents

- $\quad$ Reduce the incentive of suppliers to compete vigorously; reduce mobility of consumers between suppliers

If a more in-depth investigation reveals that there is an undue restriction on competition, the Toolkit contains advice on alternatives that may offset or mitigate potential harm to competition while still achieving the policy objective of the original law/regulation.

The multi-year Mexico-OECD Co-operation to Strengthen Competitiveness project in Mexico is done in co-operation with the Mexican Federal Competition Commission and the Ministry of Economy.

Source: www.oecd.org/daf/competition/assessment-toolkit.htm. 
New federal regulations are already subject to a regulatory impact analysis by the regulatory assessment agency (COFEMER) prior to promulgation that assesses the costs of regulations against their potential benefits, including consultation with the competition agency when required. COFEMER introduced mandatory competition assessment of new regulations developed by the federal government in March 2013. These regulatory reviews require consultation with the COFECE on matters that are suggested as problematic. Continued focus on this area will be necessary to ensure that ministries appropriately identify regulations that may restrict competition. Consideration of the competition impacts of regulations does not regularly occur at the municipal and state level, despite the fact that many regulations are made at this level. Local regulations may, for example, restrict competition in several markets - as happens with Tortilla producers - provide protections to professional associations, or have procurement procedures that may facilitate bid rigging.

Greater focus on municipal and state restrictions on competition could provide significant economic benefits. Efforts to roll back regulation at the state and local levels have encountered substantial difficulties and setbacks (see OECD, 2014a), despite a variety of regulatory and competition programmes to address problems. Application of the OECD's Competition Assessment Toolkit should be of help in diagnosing potential areas to address (see Box 1). A draft Presidential Decree would require a full review of the entire existing stock of regulation and mandate removal or revision of regulations that cannot be justified. This effort should be carried out with urgency, and even more importantly, an analogous one should be developed at the sub-national level that provides strong reform incentives for local governments.

\section{Box 2. Estimates of the GDP impact of structural reform}

Constitutional reforms and secondary legislation have already lowered restrictiveness in the energy and telecom sectors by a large margin - amounting to an approximately $19 \%$ reduction in product market restrictiveness for upstream service sectors. Estimates based on reforms of similar magnitudes suggest that the level of total factor productivity could be boosted by $2 \%$ of GDP in 2018 , or about $1 / 2$ per cent annually, assuming elasticities estimated across OECD economies. This would occur through accelerated total factor productivity convergence to the global technological frontier, as well as through the effects of capital deepening. These estimated effects would be magnified further through the natural evolution of the indicators as market shares of new entrants rise following the opening of these formerly uncontested sectors. These baseline estimates only include two of the multiple sectors affected by the reforms, and are below those of the Mexican government, whose estimates looked at a broader set of reforms in additional sectors. The IMF has estimated in its 2014 Article IV of Mexico that the effects of reforms could boost growth by about $3 / 4$ percent of GDP over the coming decade.

Figure 10. Reforms will boost growth

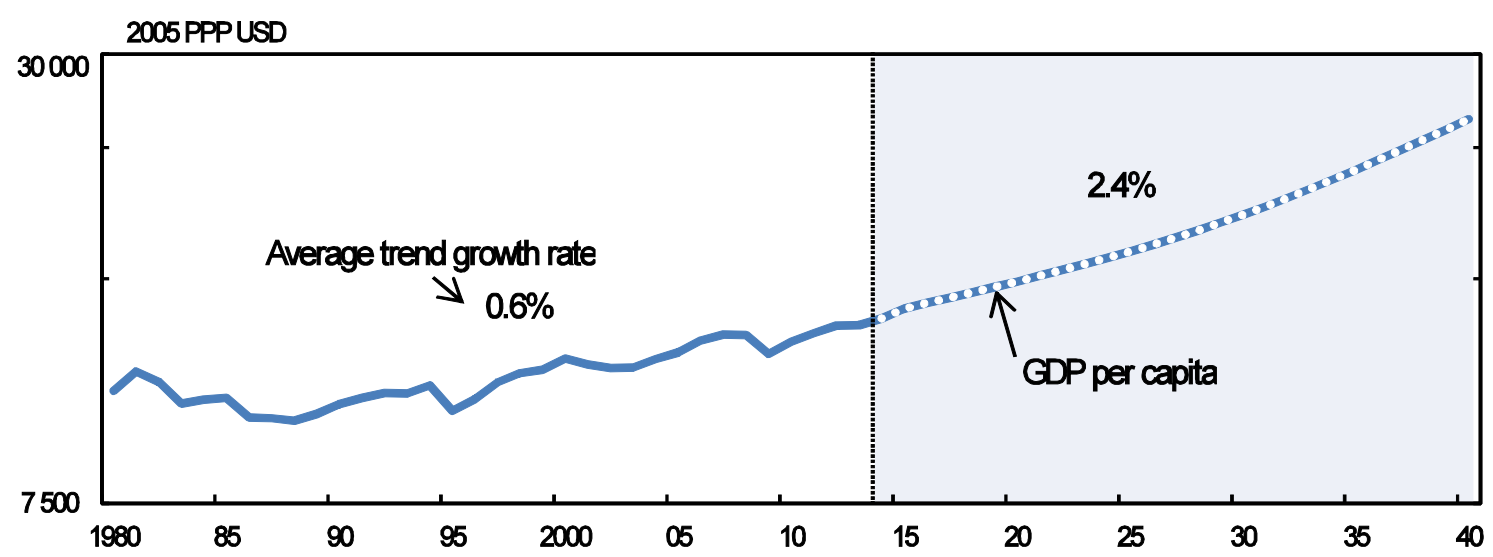

Source: OECD Long-term Growth Scenarios database; Johansson et al. (2011). 
Table 5. Impact of reform on the level of GDP in the medium term

\begin{tabular}{|c|c|c|c|c|}
\hline \multicolumn{5}{|c|}{$\begin{array}{l}\text { OECD estimates of legislated and envisioned reforms }{ }^{1} \\
\text { Impact after } 5 \text { years, assuming immediate implementation }\end{array}$} \\
\hline & $\begin{array}{l}\text { via productivity } \\
\text { growth (\%) }\end{array}$ & $\begin{array}{l}\text { via capital } \\
\text { deepening (\%) }\end{array}$ & $\begin{array}{l}\text { via employment } \\
\text { growth (\%) }\end{array}$ & $\begin{array}{l}\text { GDP growth } \\
\text { (\%) }\end{array}$ \\
\hline A. Pacto por Mexico Reforms: & 0.41 & 0.51 & 0.03 & 1.0 \\
\hline \multicolumn{5}{|l|}{ 1. Product market regulation } \\
\hline a) Telecoms & 0.06 & & & 0.06 \\
\hline b) Electricity \& gas & 0.32 & & & 0.32 \\
\hline c) Petroleum & & 0.45 & & 0.45 \\
\hline \multicolumn{5}{|l|}{ 2. Labour market reform } \\
\hline $\begin{array}{l}\text { Employment } \\
\text { protection }\end{array}$ & & & 0.03 & 0.03 \\
\hline 3. Tax structure & & 0.07 & & 0.07 \\
\hline 4. Legal reform & 0.03 & & & 0.03 \\
\hline B. Additional Reforms: & 0.91 & 0.00 & 0.10 & 1.0 \\
\hline 5. Judicial reform & 0.50 & & & 0.50 \\
\hline \multicolumn{5}{|l|}{ 6. Labour market reform } \\
\hline $\begin{array}{l}\text { a) Pro-formality } \\
\text { reforms }\end{array}$ & 0.42 & & & 0.42 \\
\hline $\begin{array}{l}\text { b) Female } \\
\text { participation }\end{array}$ & & & 0.10 & 0.10 \\
\hline Total & 1.82 & 0.51 & 0.13 & 2.0 \\
\hline \multicolumn{5}{|c|}{$\begin{array}{l}\text { (1) Note: The financial reform and the educational reform are also likely to have a significant impact in growth (the late } \\
\text { mainly in the long term), but have not been included in the table because of difficulties quantifying the impac } \\
\text { Refer to Technical Annex } 2 \text { for more details. }\end{array}$} \\
\hline \multicolumn{5}{|c|}{$\begin{array}{l}\text { Source: Bourlès et al. (2013); USEIA (2014); Bassanini et al. (2009); IMF-OECD-World Bank (2014); Dougherty (2014) } \\
\text { Dougherty and Escobar (2014); Thévenon et al. (2012). }\end{array}$} \\
\hline
\end{tabular}

\section{The impact of reforms}

Given the high intensity of structural reforms carried out in the context of the Pact for Mexico, an important question regards the pace and scale of the impact on productivity growth and GDP per capita. The intensity of Mexico's structural reforms have been impressive, making one of the most active reformers in the OECD, yet structural reforms take time to yield gains. Analysis in Getting It Right (OECD, 2012b) and the last Economic Survey based on the Long-term Growth Scenarios (or OECD@100) suggested that potential GDP growth was likely to be around 31/2 per cent annually, assuming a moderate pace of reform. An upside scenario suggested that $4 \%$ growth could be feasible with more reform intensity.

Recent estimates carried out in the context of OECD's contribution to the G20 have sought to quantify the impact of a particular package of reforms (IMF-OECD-World Bank, 2014). These were based on reforms in a number of different areas, but the most relevant for the present purposes are the estimates done using the sectoral-wise product market regulation (PMR) indicators. In Mexico's case, more precise estimates of the size of reforms is now available (Box 2). These are very close to the baseline assumed in the simulations, suggesting that GDP per capita could indeed be boosted substantially, and combined with estimates of the effect of reform in other sectors, a boost to growth in the range of one percentage point of GDP growth annually could be hoped for in the coming decade, assuming effective implementation (Table 5). These effects could be even larger if even deeper institutional reforms are completed, as discussed below. 


\section{Reducing informality and modernising the state}

\section{Promoting formality}

Formal employment is essential both to improve inclusion and increase productivity: formality enables workers to have access to social rights - such as unemployment insurance, health care and pensions - and allows business to expand, modernize, innovate and become more productive. If formality increases, the vulnerability of social institutions will recede, fiscal revenues will increase and long-term sustainability of social entitlements will be strengthened. Yet $57 \%$ of workers have an informal employment relationship and a majority of small businesses still operate in the informal sector. The reluctance to operate formally reflects a variety of factors, including stringent regulation, but also corruption and weak enforcement of basic legal rights (OECD, 2013a). The comprehensive labour reform law of late 2012 contained initiatives intended to stimulate the creation of formal employment. Several aspects of the law were innovative in the Mexican context: i) new short-term training contracts, which should have helped to improve job matching especially for the youth and lower-skilled; $i$ ) new grounds for termination without liability are now allowed for misconduct; and iii) back-pay while labour litigation is in progress is now limited to a maximum of 12 months, reducing employer uncertainty (rather than unlimited as before). Since its adoption, growth of formal employment has been more rapid than GDP growth, suggesting that the new reforms are helping.

The recent wide-ranging fiscal reform included the creation of a new regime for micro and small firms that offers a variety of incentives to promote formalisation of the workforce. The new regime, which took effect in January 2014, replaces the previous REPECOS regime, and is similar to those that Brazil followed to reduce its informality rates. Mexico's new "RIF" (Régimen de Incorporación Fiscal) fiscal regime for small firms grants several benefits to taxpayers, including:

- $\quad$ A $100 \%$ discount upon Income Tax (ISR), Value Added Tax (IVA), and excise taxes (IEPS) during the first year, that will decrease $10 \%$ each year, for 10 years.

- Simplified mechanisms to calculate and pay taxes and to file tax returns.

- To foster a taxpaying culture, taxpayers enrolled in the system will benefit from access to special development bank financing, other financial support given by the National Institute of the Entrepreneur, and training offered by the Tax Authority (SAT).

- Business owners as well as their workers will have access to housing and consumption credits from the Federal Agency for Workers Consumption (INFONACOT) and the Federal Agency for Workers’ Housing (INFONAVIT).

Further fiscal measures that took effect in July 2014 consist of subsidizing part of the social security contributions made by workers and employers (also see Chapter 2 ). This includes a $50 \%$ subsidy during the first year, which then decreases to $10 \%$ in the tenth year. An upper limit of three times the general minimum wage has been set, thus favouring lower income workers.

A communication campaign called "Let's Grow Together" was launched by the President in September 2014 which seeks to build further on the fiscal measures, and co-ordinate information campaigns with the major business organisations and working groups in all 32 state-level governments. As part of this effort, labour inspections of enterprises regarding the fulfilment of social security obligations are being strengthened. During 2013, more than 43000 inspections were carried out in workplaces under federal jurisdiction with this purpose. Enhancing enforcement is particularly important in light of evidence suggesting that it can be the most effective way of reducing informality in the short run (McKinsey, 2014). 
Figure 11. Formality tends to increase with plant size

Share of total employment across plants

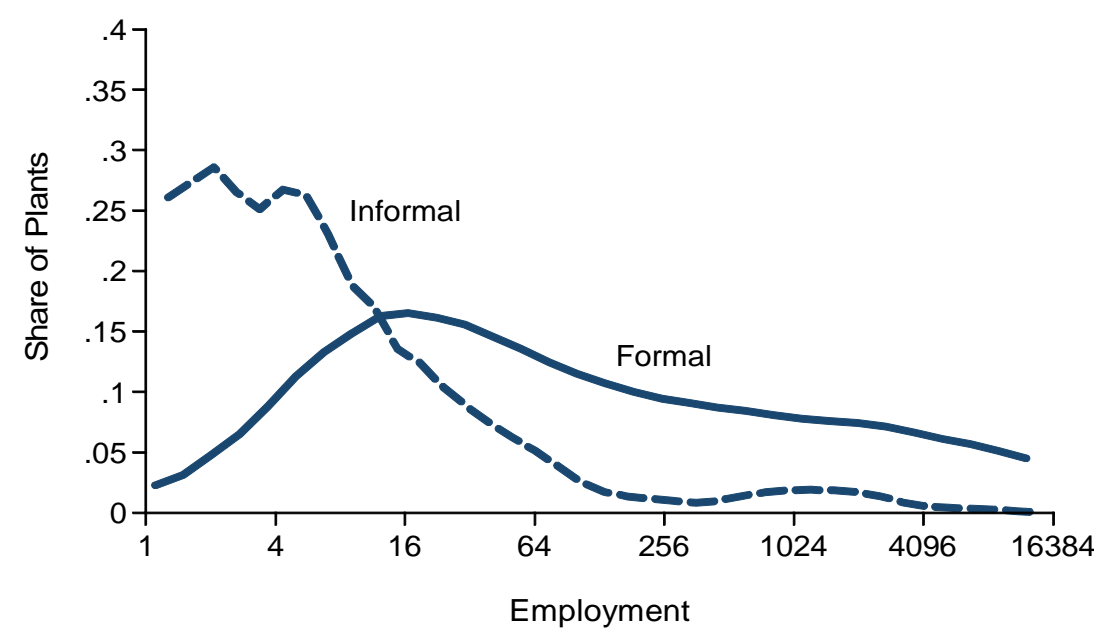

Source: Hsieh and Klenow (2013).

Longer term, the strengthening of state institutions that help to encourage formality and discourage informality needs to be addressed in order to boost productivity in a durable way (see Box 3). While the measures recently introduced go in the right direction and will help to reduce informality, evidence presented in the previous OECD Economic Survey (OECD, 2013a) showed that there was no "silver bullet”: a broad package of polices will be needed, including ongoing improvements to educational outcomes, reforms of business regulation, strengthened legal institutions and reduced corruption. All of these reform measures would help to boost firms' sizes, pushing them and their employment into the formal sector (Figure 11), and it is easier to ensure that larger firms follow the rules. This empirical evidence complements that of a number of studies that have shown that formalisation could help to enhance productivity in Mexico (Levy, 2010). 


\section{Box 3. Informality and productivity}

Informality has important implications for productivity, economic growth, and inequality of income (OECD, 2009). Informal employment is strongly linked to a firm's productivity. Trying to escape the control of authorities, informal firms remain small, adopt fewer productive technologies, use irregular procurement and divert resources to hide their activities. For example, informal firms may prefer informal financing since bank financing makes it difficult to mask their activities from authorities. This misallocation of resources harms informal firms' productivity. Because informal firms are generally less productive, aggregate productivity is reduced (Loayza et al., 2009). In addition, informal activities use public goods and services without contributing the tax revenue to finance these goods and services. Since public goods and services complement private capital in the process of production, a larger informal sector implies lower productivity growth.

In recent years, the share of informal employment has increased in about two-thirds of Mexico's states, varying from $80 \%$ in one of the poorest to $45 \%$ in one of the richest. The differences across states in terms of informal employment can be helpful in explaining disparities in economic growth outcomes. Dougherty and Escobar (2014) study the determinants of informal employment using diverging outcomes across states and time to identify causal factors. Estimates using the annual manufacturing census illustrate that the effects of informality can affect high and low productivity sectors differently. For instance, panel data estimates of the effect of informality on total factor productivity, including fixed effects and a set of control variables, imply that the magnitude of the effect is highly heterogeneous, depending on whether sectors are at the bottom or top of the productivity distribution.

As shown in the Figure below, the detrimental effects of high informality is higher in the most productive sectors and lower in the least productive sectors. This is a result of negative spillovers from the diversion of labour away from highproductivity activities, diminishing the potential positive economy-wide benefits that this reallocation could have. As a result, the benefits of tackling informality would be higher for the most productive industries within states.

\section{Figure 12. High informality rates are the most damaging for productivity}

Effect on TFP index from above or below-average informality rates

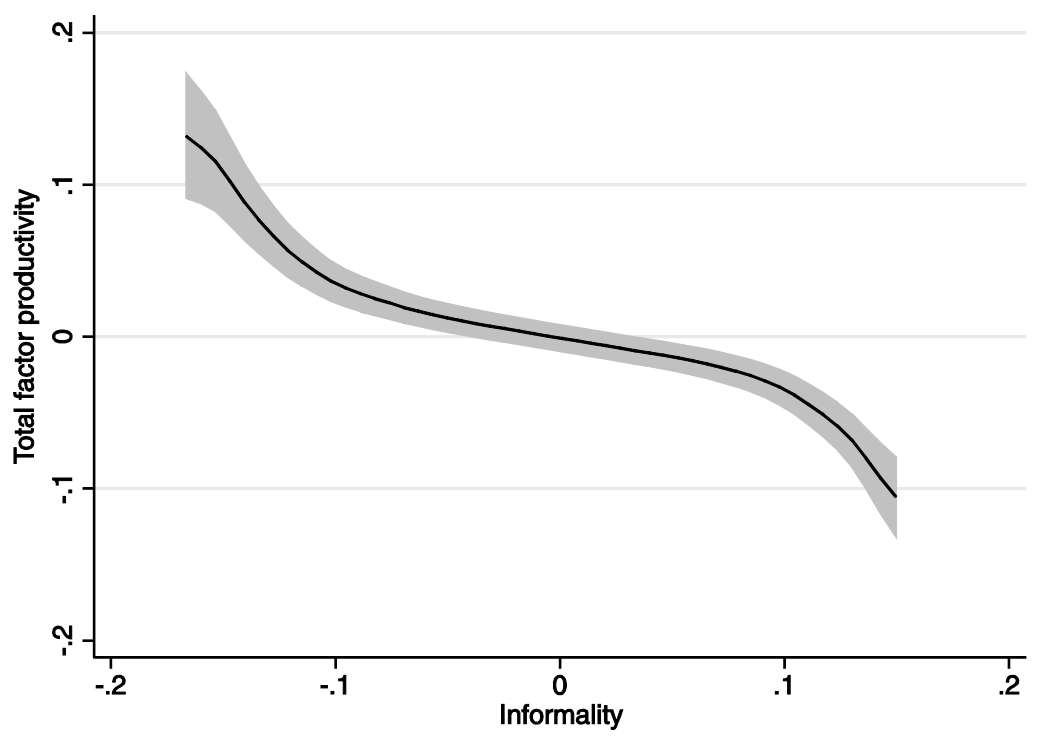

Notes: Residuals based on a fixed effects panel regression of TFP on industry-state informality rates and a set of control variables.

Source: Dougherty and Escobar (2014).

\section{Improving the judicial system}

Boosting productivity and fully benefitting from the structural reforms passed by the government will require stronger judicial institutions to enforce laws and adjudicate disputes (Figure 13). Essential in this effort is the efficiency of the court system, which depends heavily on the quality of its personnel and the soundness of procedures (Palumbo et al., 2013). Reliable enforcement of contracts gives agents incentives to save and invest, by protecting the returns from their activities. Empirical estimates carried out in the context of the last Economic Survey (OECD, 2013a) suggested that there was considerable scope to boost 
the quality of the judiciary in Mexico, since a low-quality judiciary makes contract enforcement and insolvency procedures problematic, lowering the average size of firms and their capital intensity, thus reducing aggregate productivity substantially (Laeven and Woodruff, 2007; Dougherty, 2014).

Figure 13. Adherence to the rule of law is relatively weak

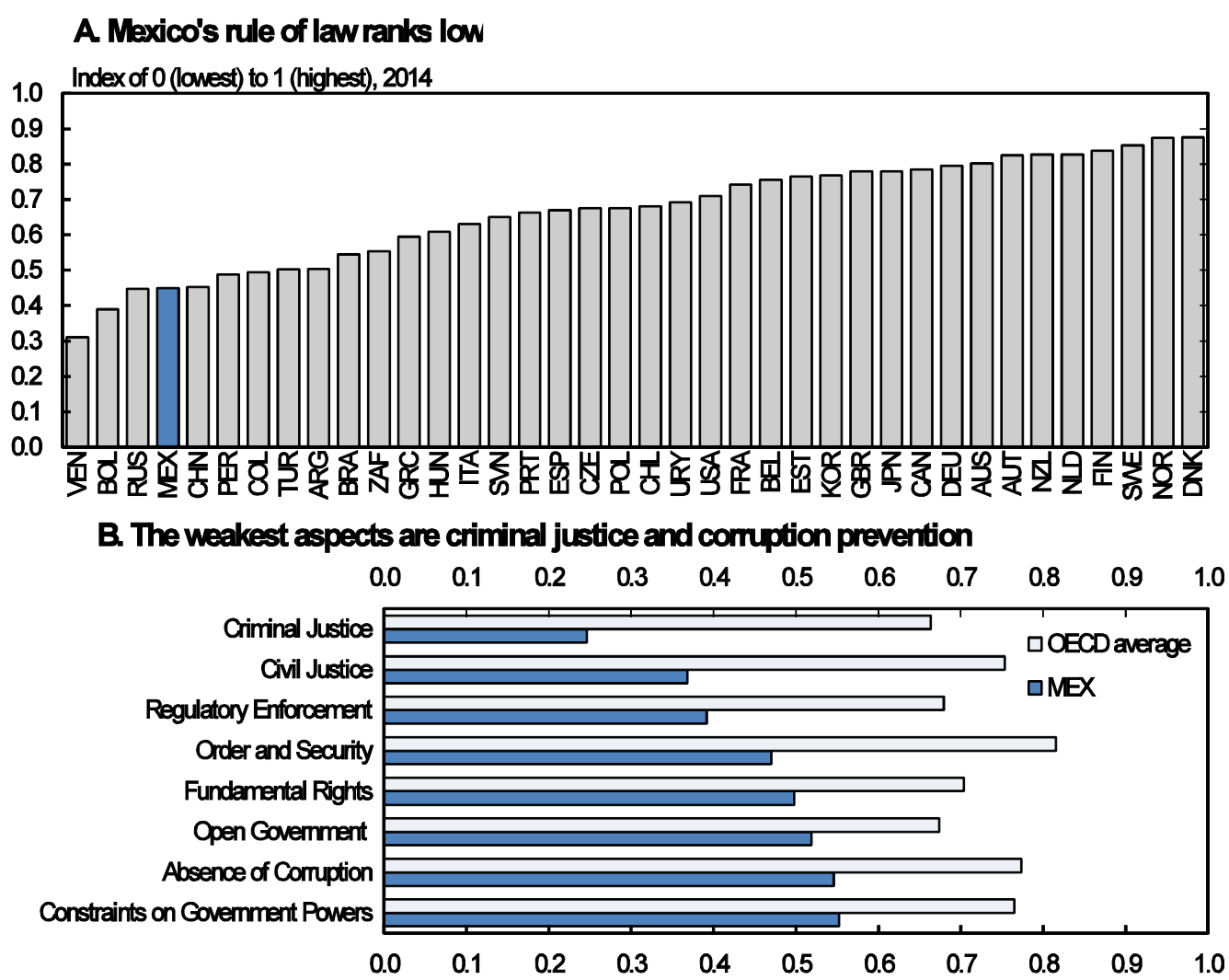

Note: The WJP Rule of Law index is a quantitative assessment tool designed to offer a picture of the extent to which countries adhere to the rule of law in practice.

Source: The World Justice Project (2014), www.worldjusticeproject.org.

Improving criminal justice is not only important for the economy, but is also crucial to improve personal safety which is a major challenge for well-being in Mexico. Some progress has been made in pursuing reforms of the criminal judicial system, from a written system that was slow and lacked credibility, to an oral "adversarial” one, called the Nuevo Sistema de Justicia Penal (NSJP). Data from the judicial reform supervisory body (SETEC) suggests that average trial times have been cut, from 343 days using the old system to 132 days using the new one. The new system is fully operational for state-level offenses (for all cases) in only four states (Table 6), while it is partially operational in certain districts of 21 more states as of November 2014.

More rapid implementation will be needed in order to meet the target of June 2016 foreseen in the 2008 Constitutional Amendment mandating a move to the new system, especially since half of the states do not yet have significant experience using the new system. A new evaluation and monitoring body as well as local working groups were set up in July 2014 to assist in accelerating the NSJP implementation. 
Table 6. Gradual implementation of new system trials for criminal cases

\begin{tabular}{|c|c|}
\hline Stage & States \\
\hline Fully operational (4) & $\begin{array}{l}\text { Chihuahua (2007), Morelos (2008), Estado de México } \\
\text { (2009), Yucatán (2011) }\end{array}$ \\
\hline Partially operational (21) & $\begin{array}{l}\text { Oaxaca (2007), Zacatecas (2009), Durango (2009), } \\
\text { Baja California (2010), Guanajuato (2011), Nuevo León } \\
\text { (2012), Chiapas (2012), Tabasco (2012), Puebla } \\
\text { (2013), Veracruz (2013), Coahuila (2013), Tamaulipas } \\
\text { (2013), Querétaro (2014), Quintana Roo (2014), San } \\
\text { Luis Potosí (2014), Guerrero (2014),Jalisco (2014), } \\
\text { Sinaloa (2014), Aguascalientes (2014), Hidalgo (2014), } \\
\text { Colima (2014) }\end{array}$ \\
\hline Formally committed (7) & $\begin{array}{l}\text { Campeche (2014), Nayarit (2014), Tlaxcala (2014), } \\
\text { Distrito Federal (2015), Baja California Sur (2015), } \\
\text { Michoacán (2015), Sonora (2016) }\end{array}$ \\
\hline
\end{tabular}

Source: SETEC, November 2014.

A key enabling step was taken with the adoption of a unified national code of criminal procedure that was published in March 2014. Prior to the passage of the new criminal code, each state had its own procedures, which was a major barrier to implementing the 2008 reforms. The code seeks to standardise procedures involving investigations, arrests, charges, hearings, sentencing, alternative dispute resolution, and reparations, while ensuring the rights of all interested parties throughout the judicial process. The new code standardises crimes nationally and gives clear and transparent guidelines for how trials should be carried out. For federal offenses, the operation of the new criminal justice system began with two states in 2014 (Durango and Puebla).

Extension of the judicial reforms to the civil and commercial domains, which only started recently, has gathered speed. Now 26 states (all except Coahuila, Colima, Guerrero, Jalisco, Oaxaca, and San Luis Potosí) use new oral trial procedures in the commercial (mercantile) domain, while four states (Guanajuato, Nuevo León, Quintana Roo, and the DF) use the procedures for civil cases. Trial times have been shortened dramatically, as in the criminal domain. A key means of shortening civil trial times has been the introduction of alternative dispute resolution, which allows for out-of-court settlements and is being used in $70 \%$ of new system cases.

Reforms of certain aspects of the judicial process have also helped considerably. Most notable is the 2013 legislation on Mexico's amparo or "habeas corpus" petitions, a reform that now prevents firms from readily blocking regulators' legitimate actions while decisions are under appeal. Although the reform expands the scope to block arbitrary government action - particularly for oppressed groups - judges will now have to give more consideration to the legitimacy of a complaint and the negative effects of a suspension of government decisions. Moreover, in the competition policy domain, since 2013, specialised judges with relevant training and knowledge are adjudicating cases in dedicated courts. These are based in Mexico City but have nation-wide (Federal) jurisdiction.

\section{Corruption}

1.1 The motivation for recent reforms of the anti-corruption system is a public sector that is perceived as relatively corrupt compared to most OECD countries (Figure 14). The weak system also encourages private sector actors to offer large bribes, as has been alleged in the cases of the business groups Wal-Mart and Citigroup, which have both taken substantial advance charges against future earnings in expectation of penalties to be assessed under the US Foreign Corrupt Practices Act for their companies' activities in Mexico. While the extent of corruption is partly due to the inefficiency of the legal system that prosecutes few crimes, it also results from other institutional weaknesses such as weak enforcement, lack 
of constraints on government power and insufficient transparency (see Figure 1.13, Panel B). Corruption fosters a variety of illegal activities, including non-compliance with tax laws and regulatory obligations. Evidence included in the last Economic Survey showed that the degree of corruption in Mexican states is causally linked to the size of the informal sector. Making it easier for informal firms to join the formal sector is an important way to reduce the main incentives for corrupt behaviour, such as what is done in the new transitional pro-formalisation tax regimes in the recent fiscal reform.

Figure 14. Mexico's public sector is perceived as corrupt

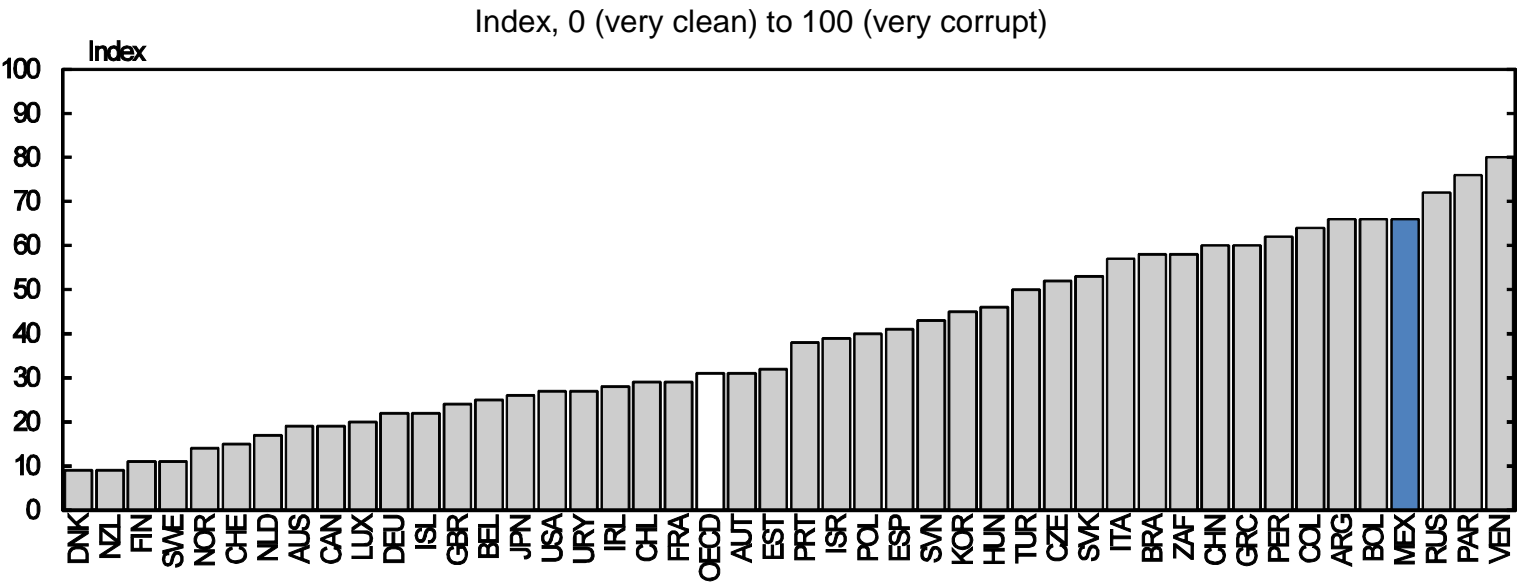

Note: The Corruption Perceptions Index ranks countries and territories based on how corrupt their public sector is perceived to be.

Source: Transparency International (2014).

Given high crime rates in many states, which directly reduce well-being and deter investment, an important priority of the government has been to improve security. Further professionalisation of police forces at all levels has been needed for some time, along with improved co-ordination amongst them (OECD-IMCO, 2013; OECD, 2013a). The administration initially focused on augmenting these forces by recruiting and training a rapid-reaction "Gendarmerie" force of highly trained Federal police, similar to those in France, Spain, Chile and elsewhere. While originally conceived as a larger force, it will start with 5000 members, expanding to 16000 by 2018. This size compares to the existing 36000 member federal police force. Security coordination and training is now being improved amongst federal, state and local governments, though the scale and pervasiveness of organised crime is a major challenge. The military still plays an important backup role in addressing security challenges in problem areas.

To promote clean government, a new anti-corruption authority has been proposed that would be responsible for preventing, investigating and handing down administrative sanctions for graft-related offenses. The bill to establish the authority has been modified and still needs to be passed in Congress. Branches of the watchdog will be set up in all of Mexico's states to ensure that public employees act with "principles of legality, honesty, loyalty, impartiality and efficiency". The administrative sanctions that can be handed down against corrupt officials include removal and disqualification from office and fines. The authority also will work closely with prosecutors in the event of criminal offenses and can recommend precautionary measures such as pre-trial detention and the freezing of assets. Meanwhile, a special office in the Federal Prosecutor's office has been established by statute to target corruption and money laundering.

A broad political reform that allows for re-election of most offices passed at the Federal level. This is a welcome development that has been long advocated by the OECD in its Getting It Right reports (OECD, 2007, 2012b). The new political reform law - which States are required to implement by 2018 - will allow future senators, deputies, mayors and local lawmakers to run and serve for consecutive terms (the President 
is not included). These new rules should strengthen the incentives of local governments to provide higher quality services, and are complemented by laws requiring greater transparency of government finances. These rules should be adopted with expediency by states in order to promote stronger incentives for good governance.

\section{Agricultural policies and land reform}

Agriculture remains an area in need of fundamental reform: while it employs over $13 \%$ of the workforce, it accounts for only 3.5\% of GDP. An important part of boosting productivity is for Mexico to further promote labour reallocation from low to high productivity sectors. Barriers to reallocation have meant that labour resources are misallocated, reducing productivity growth. Complexities in transferring land titles for communal land plots, called ejidos, which cover half of Mexican territory, have been a major obstacle. The property rights arrangements for this land promote small scale farming, limiting economies of scale. Evidence suggests that the transfers of the land to private hands can alter the incentives for investment and thus boosts agricultural productivity substantially (Castañeda Dower and Pfutze, 2013).

A significant simplification of the land certification and transfer process is now needed to ensure more productive use. While a Constitutional Amendment in 1992 allowed these plots to be delineated and transferred, only $2.5 \%$ of the land entered into the private domain over two decades (Dell, 2012). This partly reflects the inherent difficulties in reaching agreement among a large number of co-owners, and ensuring that they are each compensated fairly. The recent energy reform provides one avenue for alternative use, through its requirement that land be yielded for rent or sale at market prices (with statutory royalty fees) when energy projects require access (Payan and Correa-Cabreara, 2014). Political factors have tended to limit various administrations from encouraging land transfers more aggressively. This partly reflects the inherent "insurance" dimension of the land for some farmers; however, these concerns can be better met through increased access to finance to encourage gains from land sales to be invested wisely, as well as benefit programmes that can provide an effective social safety net (see Chapter 2).

More broadly, agricultural subsidies need to be reformed, as they promote inefficient use of land. While the overall level of producer support is low in Mexico, it is heavily skewed towards input and production-linked support (Figure 15), and tends to be regressive, thus benefitting the richest farmers. The PROAGRO program introduced last year shifts from subsidies to "productive" incentives and is therefore welcome (OECD, 2014c), as is the intention to differentiate subsistence and commercial agriculture. Unlike the previous programme PROCAMPO, the new payments are linked to specific actions to improve land productivity, and they are required to plant. Farmers will have to give proof that the payment has been used for technical, productive, organisational or investment improvements, that is, technical assistance, machinery, certified seeds, fertilisers, restructuring, insurance or price hedging. However, the link between producer support and use of inputs should be reconsidered, as this can lead to inefficient distortions. Programmes to offer collective-based financing for smaller famers could also be further strengthened. Beyond this, it will be important to phase out subsidies to electricity for pumping water, as agriculture currently represents over $75 \%$ of water consumption in Mexico. Direct rural income support could be considered as an alternative, ideally channelled through targeted anti-poverty programmes (see Chapter 2 ). 
Figure 15. Producer support has declined and could be lower and less distortive

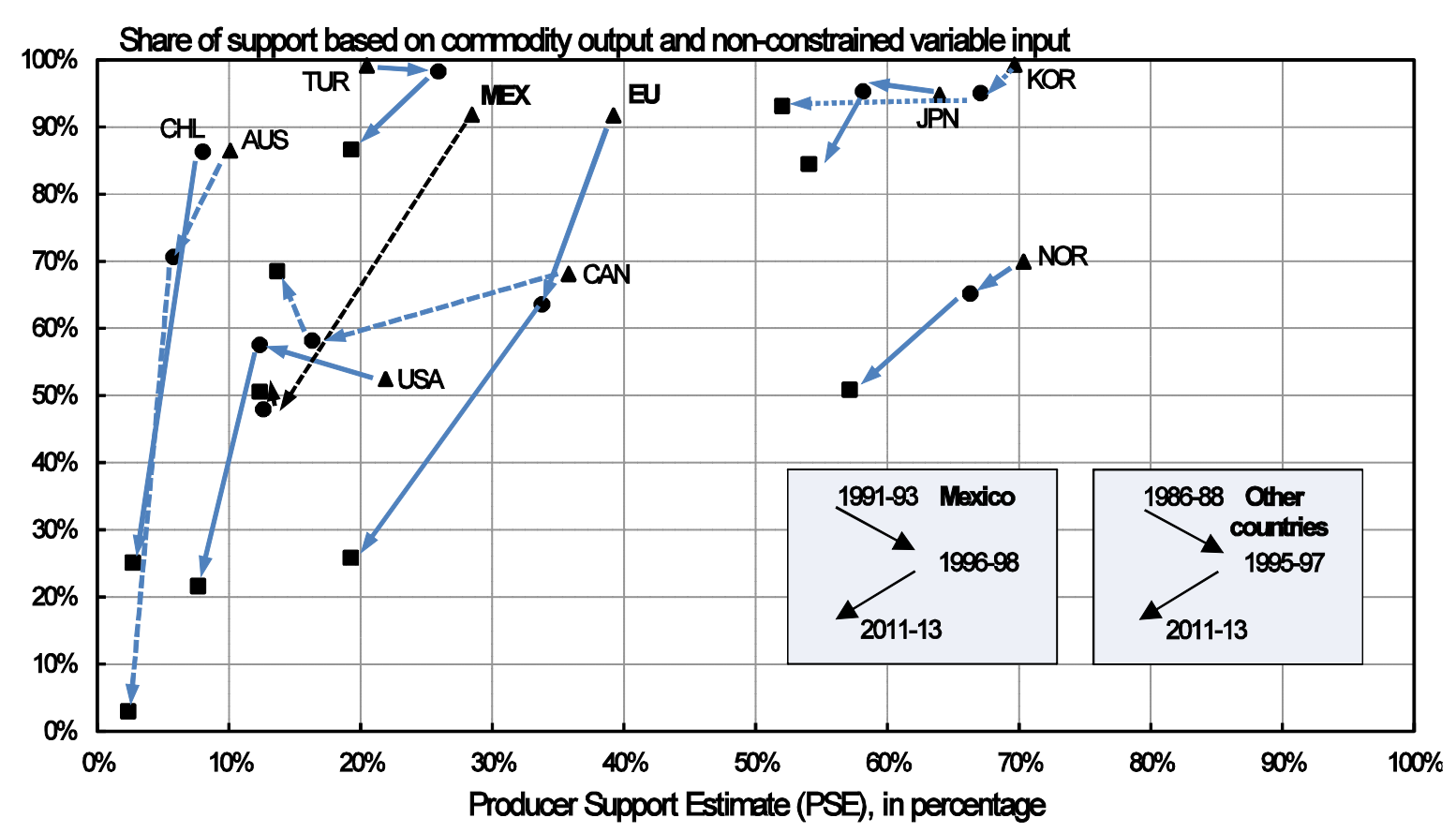

Note: The level of support is presented by the percentage PSE. The composition of support is presented by the share in gross farm receipts of Market Price Support, Payments based on output and Payments based on non-constrained variable input use.

Source: OECD (2014), Producer and Consumer Support Estimate database.

Figure 16. R\&D intensity is especially low in Mexico

Expenditure on R\&D by sector of performance, 2012

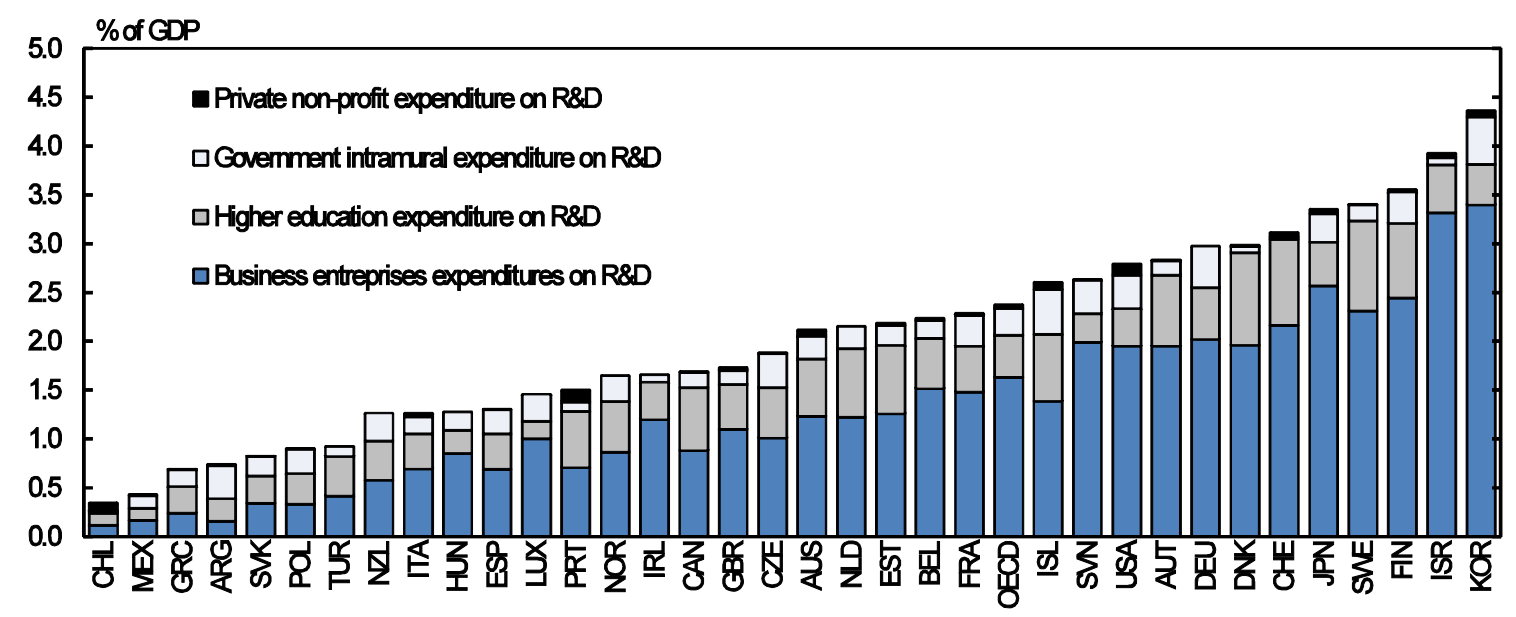

Source: OECD, Main Science and Technology Indicators database. 


\section{Strengthening the future conditions for moving up the value chain}

\section{Boosting technological absorption}

Innovation is essential to raise productivity, and here Mexico's performance has been weak. Both private and public sector R\&D investment (under 0.5\% of GDP in 2012) is well below that of nearly all OECD and emerging non-member countries (Figure 16). Mexico's President has made a commitment to raise R\&D intensity to at least $1 \%$ of GDP, but it will be difficult to achieve this objective given Mexico's current industrial structure: over one-third of manufacturing R\&D is carried out in low and mediumtechnology sectors. Moreover, obstacles to boosting the country's innovative potential include a weak domestic research and skills base, an underdeveloped knowledge-based start-up environment and institutional challenges.

On the other hand, unilateral trade liberalisation has given Mexico greater market access to hightechnology inputs, deepening its integration with global value chains (GVCs) and regional trade networks. Mexico has taken important steps to strengthen and promote the free flow of goods, services and financial resources. The country has struck free-trade agreements with 45 countries, and continues to pursue the strengthening of its trade links, reducing tariffs substantially (Figure 15, Panel A). Mexico has expanded its trade further by negotiating access to regional markets through the Pacific Alliance and is participating in FTA negotiations with the Trans-Pacific Partnership.

Figure 17. Trade liberalisation and integration has proceeded
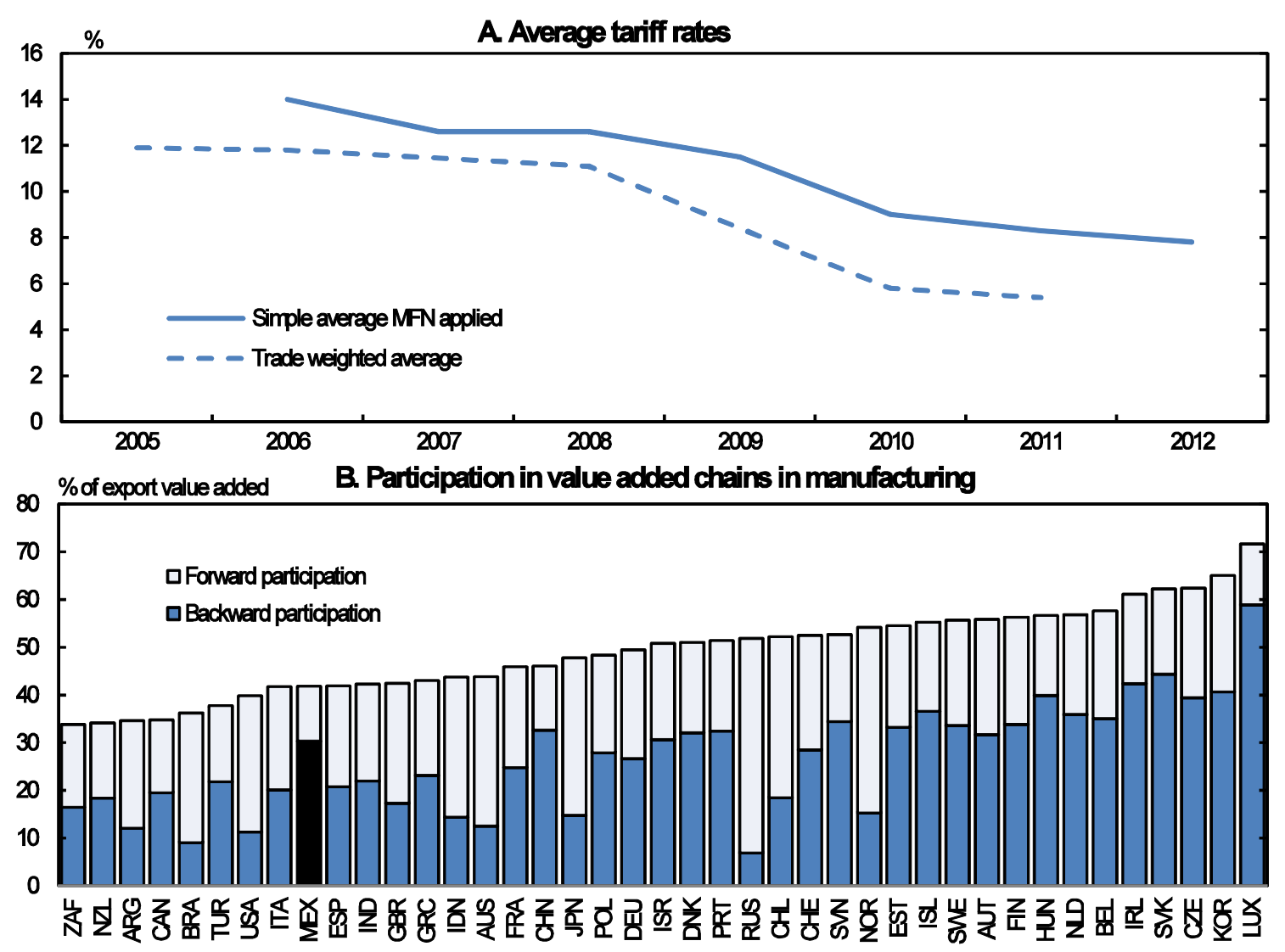

Source: OECD-WTO, Trade in Value Added database, www.oecd.org/trade/valueadded. 
Trade opening steps have helped Mexico to be relatively well integrated in global supply chains. At present, about $30 \%$ of the value added of exports consists of foreign value added, which is close to the OECD median (Figure 17, Panel B). Mexico's reliance on domestic value added (11\%) is, however, among the lowest in the OECD, as most intermediates are imported from abroad, partly reflecting Mexico's dominant role in assembly activities, chiefly in Malquiladoras. While these assembly activities have helped to boost exports and create jobs, the causal effect on productivity has actually been negative. As shown in Chapter 2, these low-skilled jobs have increased drop-out rates in schools. In order to further enhance Mexico's placement in global trade linkages, it will be important to ensure that the playing field is level for all firms, and firms are pushed to join the formal sector, as was done in last year's fiscal reform.

\section{Box 4. Services trade restrictiveness index update}

OECD Services Trade Restrictiveness Indexes (STRI) has been developed to measure the incidence of various types of barriers to services trade in specific sectors. A total of 18 sectors across most OECD countries are now covered. In the case of Mexico, particularly restrictive sectors include air transport, courier and legal services, where stringency in Mexico is well above the OECD average.

For the key sector of telecoms covered by the reforms, an update of this STRI pilot sector was carried out. The most significant change in Mexico's STRI score stems from the lift of foreign investment restrictions due to the recently amended Foreign Investment Act. In addition, based on the 2013 constitutional reform by the Congress, a new Federal Telecommunications and Broadcasting Law was passed on 11 August 2014 and is expected to enter into force as of 1 January 2015.

\section{Figure 18. Services trade restrictiveness in telecoms has been reduced substantially}

Services trade restrictiveness index restrictiveness, ranging from least restrictive (0) to most restrictive (1)
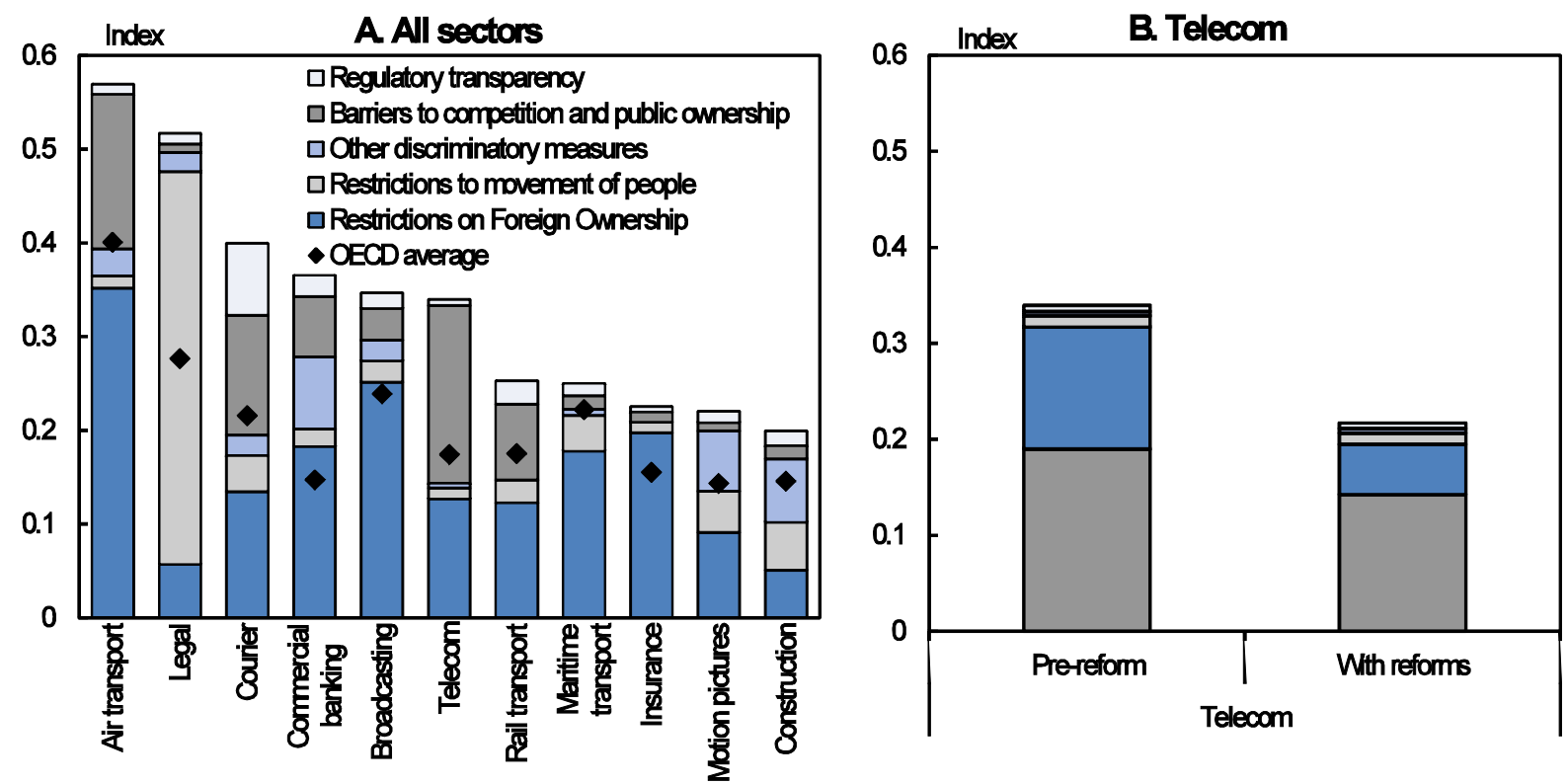

Source: OECD, Services Trade Restrictiveness database.

The major changes to the STRI score in telecoms stem from elimination of foreign equity restrictions. This reform alone reduces the STRI index by 7.5 basis points, mainly under restrictions on foreign entry. In addition an independent regulatory body, the Federal Telecommunications Institute, has been established. This is reflected in a reduction under the barriers to competition policy area. Another reform that is reflected in this policy area is elimination of minimum capital requirement, which in turn affects all sectors. These two changes reduce the STRI index by 4.7 basis points for telecoms.

The Federal Telecommunications Institute shall undertake market analysis to establish non-discrimination conditions for access to essential infrastructure resources, impose necessary measures to foster competition such as asymmetric regulation on any preponderant operator in the telecommunications market. Further reductions in the STRI index under the barriers to competition heading is expected when the regulatory authority has completed its market analysis and decided on imposing pro-competitive regulatory measures on incumbents found to have significant market power. This will be reflected in the STRI scores when a decision is made public.

Source: OECD Trade and Agriculture Directorate. 
One manifestation of the dichotomy between trade openness and domestic linkages can be seen in the productivity growth relative to the United States. Mexico's labour productivity growth in manufacturing (2.4\%) was much lower than in the same US industry (4.6\%) over the past two decades, in spite of the close integration between those countries, in particular in this industry. This fact illustrates that although industries such as electronics, aeronautics and scientific instruments are considered knowledge industries in developed economies, in Mexico they are dominated by labour and scale-intensive process with much lower productivity growth. This limits the potential convergence that could be achieved through global convergence (Rodrik, 2013).

While extensive structural reforms have taken place in certain sectors, product market regulatory stringency in the economy remains relatively high, well above the OECD average overall. This limits the ease with which new firms can enter these markets and recruit workers. The striking shift of labour away from manufacturing partly mentioned earlier in this Chapter partly reflects these issues. Beyond additional domestic product market deregulation, further reduction of trade barriers in many service sectors would also be helpful in boosting productivity (see Box 4).

\section{Creating an innovation and start-up friendly business climate}

Promoting the creation of new firms is a growing priority in Mexican innovation policy. The country has improved its legal framework to facilitate the founding and expansion of businesses. However, access to credit, especially in the seed and start-up phases, is still a relevant barrier to fostering start-ups in Mexico (OECD, 2013b, 2013c). Recent OECD evidence shows that young firms across OECD countries account for about 75\% percent of job creation (Criscuolo et al., 2014). While comparable data is not yet available for Mexico, the figure could be even higher given the large share of employment in small firms. Strengthening the start-up environment through and expansion of programmes to support currently weak angel and venture capital financing would be helpful (Figure 19).

Science and technology programmes have been evolving, with a greater focus on science. The funding available to the National Council for Science and Technology (CONACYT) was increased by 20\% in 2014. CONACYT has focused on "transversal" innovation policies that will impact development in high impact industry sectors, and helping to boost cooperation with universities, which is presently weak. One bill that has been proposed would give researchers and universities the right to develop commercial products based on publicly funded research.

Regional high-technology clusters have seen considerable growth, such as the aerospace cluster of Querétaro (Box 5), and case studies suggest that they have been able to find strong regional synergies between companies and with research and training institutions. One important question is how the government can play a positive facilitating role, such as going beyond industrial policy and helping build networks among businesses as well as between business and academic institutions. 
Figure 19. Targeted policy tools to promote start-ups
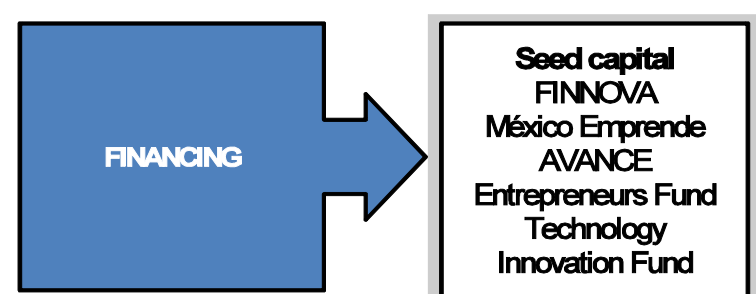

\begin{tabular}{|c||}
\hline Angal imvestors \\
Networks \\
Angel Ventures \\
Startup Factory \\
Startup Mexico \\
Regional Startup \\
Commmities
\end{tabular}

\begin{tabular}{|c}
\hline Venture capital \\
Enterprise capital Fund \\
(NAFN) \\
Technology Innovation Fund \\
Imnovation Stimuli Programme \\
(PE)) \\
Gezelle SME Fund
\end{tabular}

Business incubators

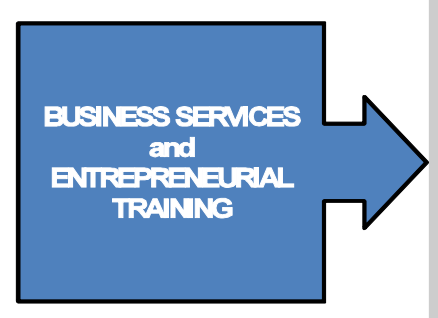

National Business Incubator System

Network of Technological University Incubators

\section{Accelerators TECHBA}

(Advanced manufacturing, ICTs, life sciences)

Business Networks oriented to Innovation (PROINNOVA)

Technological Innovation for SMES (INNOVAPYME)

AVANCE Business Schoo

ADIAT, FT Modality c, FNNOVA FUMEC

National Institute of the Entrepreneur (INADEM)
Technology transfer FNNOVA fund

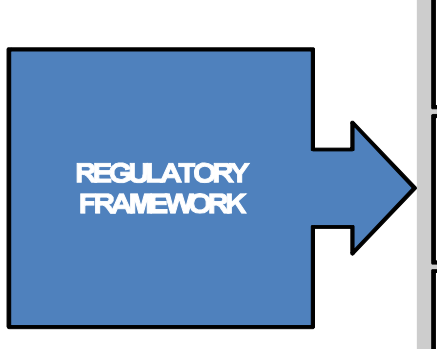

Legislation: Major reforms have significantly reduced administrative and regulatory restrictions on starting and expanding companies in Mexico

Financial reguation

Financial sector reform of 2013

Development Capital Certificates
Fiscal and tax incentives 2009 reform of the S\&T law of 2002

Special Programme of Science, Technology and Imnovation 2014-18

Key policy objective to increase R\&D intensity to $1 \%$ of GDP by 2018

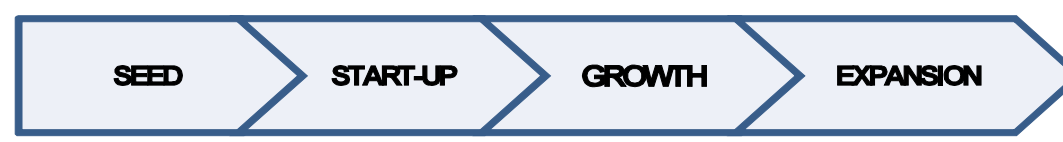

Source: OECD (2013), Start-up Latin America, OECD Development Centre, with updates. 


\section{Box 5. The Querétaro Cluster}

The aerospace sector is the fastest growing manufacturing industry in Mexico, and Querétaro is the most rapidly growing of several regional clusters in the sector (others being in Baja California and Sonora). Querétaro's development has been heavily driven by the industry itself. Key firms established in the state as anchors -- notably Canadian company Bombardier and the French Safran Group -- attracting additional related firms, eventually developing a network of local suppliers and relevant training institutions. The cluster's proximity to Mexico City has also made it easier to attract large numbers of bachelor-educated graduates, and it has begun to diversify into IT services.

Key to Querétaro's success has been the close relationship between the state government and private industry. An important co-ordination mechanism between the industry, education and research institutions is the Aerospace Research and Innovation Network of Querétaro (RIIAQ), which started in 2008 and helps develop and strengthen research, technological development and innovation capabilities.

Several training and education institutions now provide specialist courses and collaborative links with industry. Notable among these is the Aeronautical University in Querétaro (UNAQ), which is newly established public institution of higher education specializing in aircraft formations. In less than a decade, the UNAQ has grown extremely rapidly, aided by Federal government support.

Reviews of experiences with clusters in other OECD countries emphasise the potential importance of the government encouraging new firm creation, stimulating innovation, co-ordinating policies, strengthening human capital, facilitating access to finance and addressing congestion (OECD, 2009). Recent empirical evidence suggests that, after controlling for convergence in start-up activity at the regionindustry level, industries located in regions with strong clusters experience higher growth in new business formation and start-up employment (see Delgado et al., 2014). Industries participating in a strong regional cluster register higher employment growth as well as higher growth of wages, number of establishments and patenting rates, and can even enhance growth opportunities in related industries and neighbouring clusters. However, policies to promote clusters should avoid "picking winners" and focus on building on existing industry networks, enhancing infrastructure and promoting linkages with universities (Warwick, 2013).

Access to credit, especially in the seed and start-up phases, is still a relevant barrier to fostering startups in Mexico (OECD, 2013b, 2013c). Private equity and venture capital represent only $0.02 \%$ of GDP, one of the lowest figures in the region. A National Institute of the Entrepreneur was created in 2013 to refine and implement schemes to address entrepreneurs' needs, including forming a seed capital "fund of funds". Further strengthening of the start-up environment through enhancement and expansion of these programmes to support angel and venture capital financing would be especially helpful. Pacific Alliance members have been working jointly to boost SME financing, and one promising step was Mexico's joining of the Latin American Integrated Market (MILA) in 2014, making it the largest stock market in the region.

At the same time, fostering greater accumulation of human capital will be important; Mexico has one the lowest rates of doctoral degree completion in the OECD, and higher quality education more broadly will help, which means more investing in education at all levels (see Chapter 2). Strengthening coordination bodies that can help to identify the right policies can also help.

As a central part of the Programme to Democratise Productivity, a high-level consultative body - The National Productivity Commission (NPC) - was established in May 2013 to help strengthen co-ordination and help to identify the right policies. The NPC includes Federal Ministries, and the National Science and Technology Council, as well as representatives from the private sector, labour unions, and education institutions (Figure 20). The NPC contributed to the administration's Program for Democratising Productivity, which includes the Government's strategy for raising productivity in an inclusive fashion. More recently, the NPC has identified cross-cutting policy areas (such as labour training and innovation in specific sectors) in which co-ordinated actions are deemed crucial for boosting productivity. 
Figure 20. The structure of Mexico's Productivity Commission

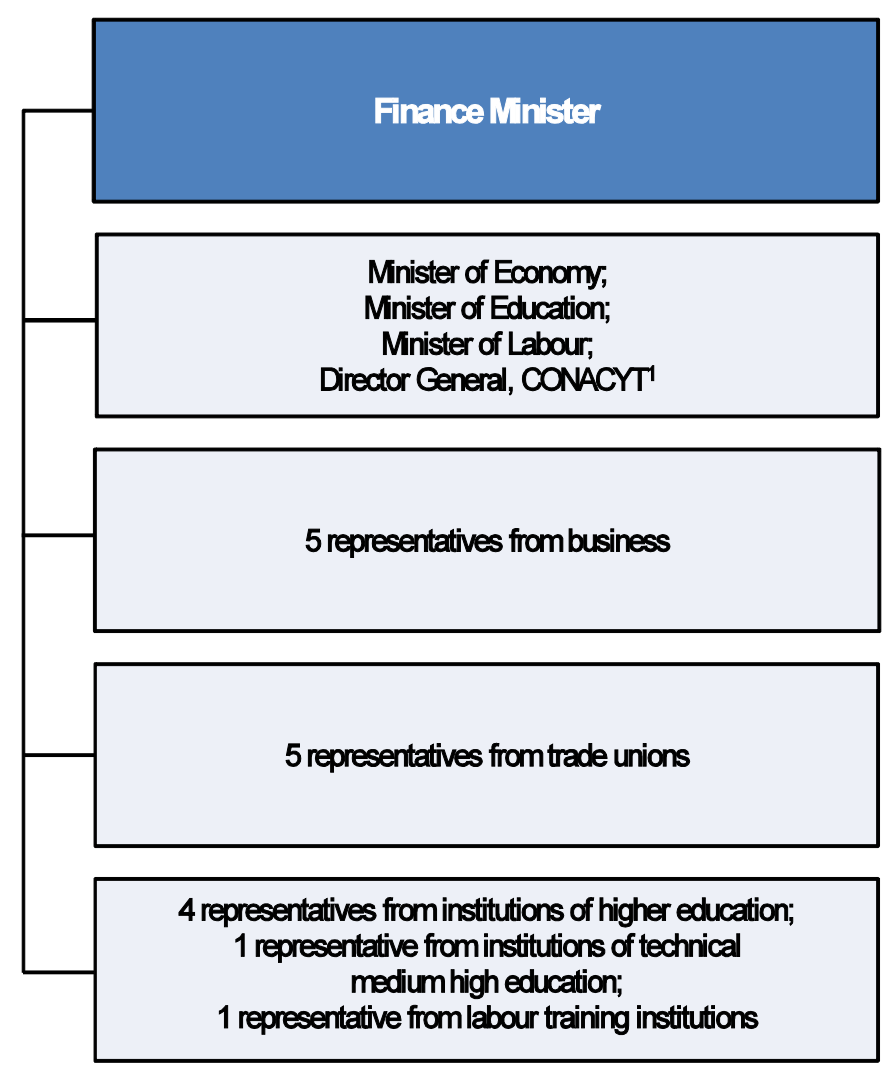

1. National Council for Science and Technology.

Source: Secretaría de Hacienda y Crédito Público de México (SHCP).

Early signs suggest that the NPC is working well, helping to analyse problems and build consensus for reform, notably in the area of public sector management. In order to have a more robust impact, it could benefit from a stronger legal framework and more systematic processes related to the legislative branch. The productivity commission with the longest experience, Australia's is noted for its independence, transparency, and community-wide perspective. Thanks to these fundamental operating principles, it has strong credibility domestically. Legislation was submitted to Congress in October 2014 that provides such a framework, focused around productivity and competitiveness, clarifying the Commission's economywide mandate and the establishing a requirement that the federal government respond to its policy recommendations; the new law should be passed and implemented. 


\section{Recommendations to boost growth and reduce informality}

\section{Main recommendations}

- Focus on fully implementing the reform package with close monitoring at a high political level, and strengthen administrative capacity and governance quality at all levels of government.

- $\quad$ Reform justice institutions, strengthen the rule of law, address security issues and reduce widespread corruption with reforms centred on the efficiency of judicial resolution of civil, commercial and criminal matters, and a strengthening of the transparency of public procurement.

- Improve and simplify the existing stock and quality of regulation at the local, state and national levels.

- $\quad$ Phase out restrictions on agricultural land ownership and transfer, while strengthening rural income support and access to finance.

\section{Additional recommendations}

- $\quad$ Promote high-tech industrial clusters with linkages to universities and early-stage investment vehicles.

- $\quad$ Address conditionality rules in the telecom reform that makes market access conditional on reciprocity.

- Examine the mandate of the new telecom competition regulator to be sure that it has enough scope of authority to deter future anti-competitive behaviours.

- $\quad$ Ensure that the new contracting rules for oil \& gas investment are carefully designed in order to provide sufficiently strong motivation for large-scale private sector participation.

- $\quad$ Promote the implementation of the new political rules that allow for re-election of state and local offices.

- $\quad$ Pass the law that establishes the Productivity Commission's new mandate.

- $\quad$ Enhance the data infrastructure for evidence-based policy making.

\section{Environment}

- The new carbon tax should be evaluated, and raised if deemed insufficient.

- $\quad$ Pass the pending renewables energy bill, and take further steps to fully implement the renewables target of $35 \%$ by 2024.

- $\quad$ Stay on track in the phase-out of the gasoline subsidy, such that gasoline prices are fully liberalised by 2018. 


\section{BIBLIOGRAPHY}

Bassanini, A., L. Nunziata, and D. Venn (2009), “Job Protection Legislation and Productivity Growth in OECD Countries”, Economic Policy, Vol. 24, No. 58.

Bouis, R., O. Causa, L. Demmou, R. Duval and A. Zdzienicka (2012), “The short-term effects of structural reforms: an empirical analysis”, OECD Economics Department Working Papers.

Bourlès, R., G. Cette, J. Lopez, J. Mairesse, and G. Nicoletti (2013), "Do Product Market Regulations in Upstream Sectors Curb Productivity Growth? Panel Data Evidence for OECD Countries”, The Review of Economics and Statistics, Vol. 95, No. 5, pp. 1750-1768.

Castañeda Dower, P. and T. Pfutze (2013), "Specificity of control: The case of Mexico's ejido reform”, Journal of Economic Behavior \& Organization, Vol. 91, pp. 13-33.

Conway, P., D. de Rosa, G. Nicoletti and F. Steiner (2006), "Product Market Regulation and Productivity Convergence”, OECD Economic Studies, No.43, 2006/2.

Crisculolo, C., P. Gal, and C. Menon (2014), “The Dynamics of Employment Growth: New Evidence from 18 Countries”, OECD Science, Technology and Industry Policy Papers, No. 14, OECD Publishing.

Delgado, M., M. Porter, S. Stern (2014), “Clusters, Convergence, and Economic Performance”, Research Policy, forthcoming.

Dell, M. (2012), “Path dependence in development: Evidence from the Mexican Revolution”, Harvard University Economics Department, Manuscript.

Dougherty, S. (2014), "Legal Reform, Contract Enforcement and Firm Size in Mexico", Review of International Economics, Vol. 22, pp. 825-844.

Dougherty, S. and Escobar, O. (2014), “Does informality reduce productivity in Mexico?”, OECD Economics Department Working Paper, forthcoming.

Chiasson, M., Ennis, S. and L. Noyola (2014), “An appraisal of Mexico's competition law and policy reforms,” OECD Financial Affairs Directorate, Competition Working Papers, forthcoming.

Hsieh, C-T and P. Klenow (2013), “The Life Cycle of Plants in India and Mexico”, Quarterly Journal of Economics, Vol. 129, No. 3, pp. 1035-84. Based on version presented at the Nobel Symposium, Stockholm University, September 2012.

IMF-OECD-World Bank (2014), Macroeconomic and Reform Priorities, Joint Report to the G20, https://g20.org/wp-content/uploads/2014/12/G-

20\%20Macroeconomic\%20Reform\%20Priorities\%20Report\%20Feb\%2012\%202014.pdf

INEGI (2013), Sistema de Cuentas Nacionales de México Productividad total de los factores 1990-2011. 
Johansson, Å., Y. Guillemette, F. Murtin, D. Turner, G. Nicoletti, C. de la Maisonneuve, P. Bagnoli, G. Bousquet, F. Spinelli (2013), "Long-Term Growth Scenarios", OECD Economics Department Working Papers, No. 1000.

Koske, I., I. Wanner, R. Bitetti and O. Barbiero (2014), “The 2013 update of the OECD product market regulation indicators: policy insights for OECD and non-OECD countries”, OECD Economics Department Working Papers, forthcoming.

Laeven, L. and C. Woodruff (2007), "The quality of the legal system, firm ownership, and firm size”, The Review of Economics and Statistics, Vol. 89, No. 4, pp. 601-14.

Levy, S. (2010), Good intentions, bad outcomes: Social policy, informality, and economic growth in Mexico, Brookings Institution Press.

Loayza, N. V., Serven, L., \& Sugawara, N. (2009), “Informality in Latin America and the Caribbean”, World Bank Policy Research Working Paper Series, No. 4888.

McKinsey \& Company (2014), A tale of two Mexicos: Growth and prosperity in a two-speed economy, McKinsey Global Institute, March.

OECD (2003), The Sources of Economic Growth in OECD Countries, OECD Publishing.

OECD (2007, 2012b), Getting It Right: Mexico, OECD Publishing.

OECD (2009), Clusters, Innovation and Entrepreneurship, LEED Reports, OECD Publishing.

OECD (2012a), Review of Telecommunication Policy and Regulation in Mexico, OECD Publishing.

OECD (2013a, 2015a), Economic Survey of Mexico, OECD Publishing.

OECD (2013b), Knowledge-based Start-ups in Mexico, OECD Publishing.

OECD (2013c), Start-up Latin America: Promoting Innovation in the Region, OECD Development Centre.

OECD (2014a), Regulatory Reform Review of Mexico, OECD Publishing.

OECD (2014b), Perspectives on Global Development, Development Centre, OECD Publishing.

OECD (2014c), Agricultural Policy Monitoring and Evaluation: OECD Countries, OECD Publishing.

OECD (2014d), "Reducing regulatory barriers to competition: Progress since 2008 and scope for further reform” in Economic Policy Reforms: Going for Growth Interim Report, OECD Publishing.

OECD (2015b), Going for Growth: Economic Policy Reforms, OECD Publishing.

OECD-IMCO (2013), Strengthening Evidence-based Policy Making on Security and Justice in Mexico, OECD Publishing.

Padilla-Perez, R. and F. Villarreal (2014), “An unfinished business: Economic liberalization and structural change in Mexico", UN Economic Commission for Latin America and the Caribbean, July. 
Palumbo, G., G. Giupponi, L. Nunziata, J. Mora-Sanguinetti (2013), "The Economics of Civil Justice: New Cross-Country Data and Empirics”, OECD Economics Department Working Papers, No. 1060.

Payan, T. and G. Correa-Cabreara (2014), "Land Ownership and Use Under Mexico's Energy Reform”, Rice University Baker Institute Issue Briefs, No. 10.29.14.

Presidencia de la República (2014), “Energy Secondary Regulation” (English version), available at www.presidencia.gob.mx/reformaenergetica/en/\#!landing (accessed October 2014).

Rodrik, D. (2013), “Unconditional Convergence in Manufacturing”, The Quarterly Journal of Economics, Vol. 128, No. 1, pp. 165-204.

Rios, V. (2012), "How Government Structure Encourages Criminal Violence: The causes of Mexico's Drug War”, Harvard University Department of Government, Dissertation.

Sutherland, D and P. Hoeller (2013), "Growth-promoting Policies and Macroeconomic Stability”, OECD Economics Department Working Papers, No. 1091.

Thévenon, O., N. Ali, W. Adema and A. Salvi del Pero (2012), "Effects of Reducing Gender Gaps in Education and Labour Force Participation on Economic Growth in the OECD", OECD Social, Employment and Migration Working Papers, No. 138.

Urzúa, C. (2013), “Distributive and Regional Effects of Monopoly Power”, Economía Mexicana Nueva Época, Vol. 22, No. 2, pp. 279-295.

USIEO (2014), International Energy Outlook 2014: World Petroleum and Other Liquid Fuels With Projections to 2040, US International Energy Administration, September, www.eia.gov/ieo.

White \& Case (2014), Energy, Infrastructure and Project Finance in Mexico, available at www.whitecase.com/files/Publication/0313f57d-2c9f-48fa-82bb055cd3ce92b2/Presentation/PublicationAttachment/7a4e6eca-f491-4aad-87ab-1932cd3dcf0c/alertenergy-reform-power-engl-03.pdf (accessed October 2014).

World Bank (2014), Doing Business in Mexico 2014, World Bank Sub-national Doing Business, May. 


\section{TECHNICAL ANNEX 1: STRUCTURAL REFORM PROGRESS}

Table A1.1. Progress on structural reforms

\begin{tabular}{|c|c|c|c|c|c|c|}
\hline Reform & $\begin{array}{l}\text { Secondary } \\
\text { legislation } \\
\text { approved }\end{array}$ & $\begin{array}{l}\text { Main } \\
\text { provisions } \\
\text { enacted? }\end{array}$ & $\begin{array}{l}\text { Constitutional } \\
\text { amendment } \\
\text { (if required) }\end{array}$ & $\begin{array}{l}\text { New or } \\
\text { empowered } \\
\text { regulator }\end{array}$ & $\begin{array}{l}\text { Legislative } \\
\text { approval }\end{array}$ & $\begin{array}{l}\text { Remaining steps to } \\
\text { be taken? }\end{array}$ \\
\hline \multicolumn{7}{|c|}{ Reforms approved and being implemented } \\
\hline Labour & Dec 2012 & Yes & - & - & Federal & - \\
\hline Amparos & April 2013 & Yes & Yes & - & Federal/ States & - \\
\hline Education & Sep 2013 & Yes & Yes & Yes & $\begin{array}{l}\text { Federal/ } \\
\text { States }\end{array}$ & Multiple stages \\
\hline Tax/Fiscal & Oct 2013 & Yes & - & - & Federal & - \\
\hline Financial & Jan 2014 & Yes & - & Yes & Federal & - \\
\hline $\begin{array}{l}\text { Transparency } \\
\text { (access to public } \\
\text { information) }\end{array}$ & Feb 2014 & Yes & Yes & Yes & $\begin{array}{l}\text { Federal/ some } \\
\text { states }\end{array}$ & - \\
\hline $\begin{array}{l}\text { National Criminal } \\
\text { Procedural Code }\end{array}$ & Mar 2014 & Partial & - & - & $\begin{array}{l}\text { Federal/ some } \\
\text { states }\end{array}$ & $\begin{array}{l}\text { States to use new } \\
\text { code by } 2016\end{array}$ \\
\hline Telecoms & July 2014 & Yes & Yes & Yes & Federal/ States & - \\
\hline Political/Elections & May 2014 & Partial & Yes & Yes & $\begin{array}{c}\text { Federal/ some } \\
\text { states }\end{array}$ & $\begin{array}{l}\text { States to adopt by } \\
2018\end{array}$ \\
\hline $\begin{array}{l}\text { Economic } \\
\text { competition }\end{array}$ & May 2014 & Yes & Yes & Yes & Federal & - \\
\hline Energy & Aug 2014 & Yes & Yes & Yes & Federal/ States & $\begin{array}{l}\text { Issue new bidding } \\
\text { rules }\end{array}$ \\
\hline $\begin{array}{l}\text { Reform of criminal } \\
\text { justice }\end{array}$ & - & Partial & Yes & - & $\begin{array}{l}\text { Federal/ some } \\
\text { states }\end{array}$ & $\begin{array}{l}\text { States should adopt by } \\
2016\end{array}$ \\
\hline \multicolumn{7}{|c|}{ Reforms yet to be approved } \\
\hline Anti-corruption and & il justice & Partial & Yes & Yes & - & Partial \\
\hline $\begin{array}{l}\text { Expenditure } \\
\text { (Pensions and UI) }\end{array}$ & - & No & - & - & & Pass bill \\
\hline Health & - & No & - & - & - & Introduce bill \\
\hline Agriculture & - & No & - & - & - & Draft bill \\
\hline
\end{tabular}

Source: OECD compilation. 


\section{TECHNICAL ANNEX 2: REFORM IMPACT ASSUMPTIONS}

These estimates are based on the following assumptions:

\section{A. Pactor por Mexico reforms:}

- 1(a) \& 1(b) follow the OECD G20 simulation approach using the Bourlès et al. (2013) framework, scaled to match actual changes in PMR as of August 2014 vs. January 2013.

- 1(c) assumes a 75\% increase in oil investment following USIEO (2014) estimates, relative to a $2 \%$ of GDP investment baseline.

- 2(a) follows the OECD G20 simulation approach using the Bassanini et al. (2009) framework, using the estimated reform of EPL in 2012 from OECD (2013a).

- 3 follows the OECD G20 simulation approach using the Johansson et al. (2011) framework, which is standard across countries.

- 4 uses Dougherty (2014) assuming incremental reforms.

\section{B. Additional reforms:}

- 5 uses one-third of Dougherty (2014) long-run impact of 8\% of GDP at five years.

- 6(a) uses Dougherty and Escobar (2014) TFP elasticity of 0.5 with a 5pp further reduction in the informality rate. Some of these pro-formality reforms have already been implemented in recent months by Mexican authorities.

- 6(b) uses the recent OECD study Thévenon et al. (2012) with half of the 2025 impact of 1\% of GDP assumed in five years. 


\section{TECHNICAL ANNEX 3: PRODUCT MARKET REGULATION}

A competitive product market environment that allows new firms to challenge incumbents, efficient firms to grow, and inefficient ones to exit, can help boost economic growth and living standards. A key policy ingredient for a growth-enhancing competition environment is for product market regulation to be set in a way that does not hamper competition. Empirical studies have shown that competition can raise overall output per capita by increasing investment and employment as well as by encouraging companies to be more innovative and efficient, thereby lifting productivity (e.g. OECD, 2003; Conway et al., 2006; Bourlès et al. 2013). In light of these economic gains, countries have, step by step, removed obsolete or badly-designed regulations in product markets over the past decades, reducing state involvement in business sectors, making it easier for entrepreneurs to create firms and to expand them, and facilitating the entry of foreign products and firms. While in some cases regulation was largely removed, in others it was replaced by better-designed legislation that can even help to enhance competition. The OECD has developed indicators starting in these areas to better measure these policies (OECD, 2014d).

The impact of reforms in key sectors of the economy can be measured and assessed to a certain degree by using product market regulation (PMR) and non-manufacturing regulation (NMR) indicators. An interim assessment was made of reform implementation up through August 2014 using the regulation indicators, as compared to the January 2013 update. For the Mexican case, the reforms were focused more on non-manufacturing sector deregulation, and thus the NMR indicator captures more of the changes in terms of alleviating the stringency of the economy. The PMR covers broader economy-wide regulation, and will likely be affected more in the longer term by the reforms.

The indicator of non-manufacturing regulation is composed of seven network sectors grouped into three mid-level indicators that cover energy (electricity and gas), transport (air, rail and road) and communication (post and telecommunication) as well as five additional service indicators. Regulation in electricity, gas and rail transport is measured through four low-level indicators: entry regulation, public ownership, vertical integration (except in communications) and market structure. The scores are measured on a scale of 0 to 6 , with 6 most stringent and 0 least stringent.

The NMR indicator for Mexico showed a decrease of 18.7\%, going from 3.00 in January 2013 to 2.44 points in August 2014. This change is explained by significant decreases in key sectors of the economy captured by energy and telecommunication low-level indicators. More specifically, the electricity, gas and telecommunications sector decreased to 31.2\%, 34.9\% and 45.9\%, respectively (Figure 6).

Progress made in the electricity sector (Figure 1) is mainly driven by changes in the entry regulation and vertical integration indicators. Prior to constitutional reforms, activities in the electricity sector (generation, transmission, distribution and marketing) were exclusively carried out by the state-owned electricity company or Federal Electricity Commission (CFE). Energy reforms made it legally possible for private firms to fully intervene in the generation and marketing of electricity and to compete in the transmission and distribution activities through contractual agreements (White \& Case, 2014). The Energy Regulatory Commission (CRE) has the legal responsibility of granting electricity generation permits and the National Energy Control Centre (CENACE) ensures legal compliance by transmission and distribution firms interacting with Federal Electricity Commission. Furthermore, the degree of separation in the value chain of the electricity sector changed to the most stringent level (no separation) to a legal separation status.

The market structure and public ownership indicators in the electricity sector remained unchanged. Nevertheless, they are subject to significant reductions in the medium and long term. The market structure indicator will gradually change as competitors react to the opening of different activities in the electricity sector hence allowing for a larger number of firms to compete in the electricity market. Finally, the public 
ownership indicator, which is measured as 'the percentage of shares owned either directly or indirectly by the government in the largest firm in each sector' has scope for greater change following more competition among private entities in the electricity value chain.

Significant decreases in entry regulation and market structure indicators in the gas sector yield a $34.9 \%$ change in the gas sector. Progress in the former indicator is greatly explained by a series of structural measures following a legislation package approved in August 2014. More specifically, reforms legalized investment in the country's oil sector for private companies and enabled the National Hydrocarbon Commission (CNH) to manage contracts with third parties and bidding processes. Additionally, the Energy Reform enabled public instrumentalities like PEMEX and CFE to use private firms in the oil sector thus explaining entry regulation indicators. Less restrictive values in the market structure indicator, defined in the PMR methodology as an average of 'the market share of the largest company in the gas industry' improved for all gas subsectors (generation, import and supply) from 2013 to 2014.

Public ownership and vertical integration indicators showed virtually no change for the gas industry under the PMR methodological standards. Secondary laws following structural reforms in the energy industry set grounds for a model that allows private firms to participate in the exploration and extraction sectors of hydrocarbons through production sharing, profit sharing and license contracts. The vertical integration indicator captured no changes for August 2014 due to changes already made in the vertical separation among segments in the gas production prior to January 2013.

A significant improvement in the entry regulation indicator within the telecommunications sector explains a decrease of more than 40 percent in this industry. The entry indicator explores the possibility of anyone entering the mobile and fixed communications market given that they meet the licencing criteria. Additionally, the indicator explores if laws restrict in at least one market the number of competitors allowed to operate a business. For years, a single operator in the telecommunications sector deterred competition within the industry, partly as a result of weaknesses in the institutional environment. Neither the existing regulators nor the legal system were able to foster competition or incentives for innovation within the sector, which explains a value of 1.5 in the entry indicator.

New laws on competition, telecommunications and broadcasting and the creation of a new regulator in this sector (IFT) additionally to a new competition authority (COFECE) were created. The IFT has 'authority to sanction anticompetitive conducts and mergers, to impose measures aimed at the elimination of entry barriers and to regulate access to 'essential inputs' among others.' In addition, a secondary measure approved in 2014 introduced the concept of a dominant player and defined it as an entity that has more than $50 \%$ of the market share in a specific segment of the telecom and broadcasting sectors. This secondary legislation outlaws interconnection fees, more strict regulation on dominant players and legal measures to force firms to share infrastructure. This explains a decrease from 1.13 to 0.61 in the telecommunications indicator of the NMR.

The economy-wide product market regulation indicators were developed by the OECD in 1998 as a means to measure how laws and regulation may affect competition. Data is obtained from questionnaires sent to member-country governments, which is later used to trace back potential policies that hinder competition among sectors (OECD, 2014d). The Product Market Regulation (PMR) indicator measures regulation at the economy-wide level. Furthermore, sector-specific regulatory issues are grouped under three broad domains: 'state control', 'barriers to entrepreneurship', and 'barriers to trade and investment' (Figure A3-1). Mexican regulatory regimes have been evaluated based on the OECD indicator system in 1998, 2003, 2008 and 2013. Regulatory reform in Mexico reduced stringency by 7.1\% from 2008 to 2013.

Evolution of the economy-wide regulation indicator from 2013 to August 2014 was insubstantial after scoring the eighteen low-level and mid-level indicators in the Mexican economy (Figure 9); there are several explanations to these findings. First, a considerable proportion of the low-level indicators take into account sectors where the recently approved reforms had little effect. 
Figure A3.1. Structure of the indicator of Product Market Regulation (PMR)

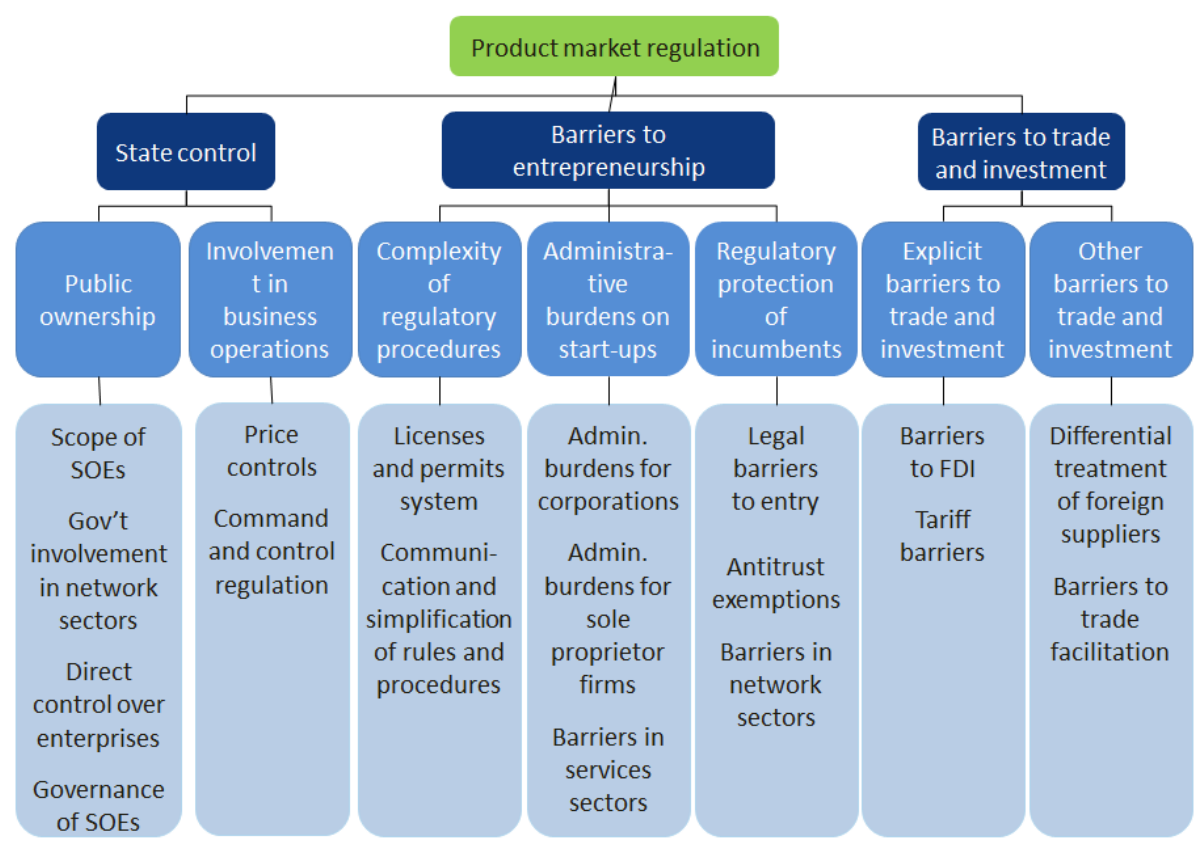

Source: OECD (2014)

Second, impact of regulations for eight out of the eighteen low-level indicators can be appreciated in the short term via the NMR indicator but only to a marginal degree via the criterion evaluated in the PMR indicator. Key aspects of the impressive wave of reforms undertaken by the Mexican government in the last few months are captured immediately by the NMR indicator but not by the PMR indicator. For example, the middle-level indicator 'state control' which concentrates mostly on sectors where reforms had an important outreach decreased only by 1.7\% from 2013 to August 2014. In addition, low-level indicators included in the state-control indicator i.e. 'scope of state-owned enterprises', 'government involvement in network sectors', 'direct control over enterprises', 'governance of state-owned enterprises', 'price controls and command and control regulation' measure the depth of the reforms less effectively than other PMR sub-indicators explained above.

Third, while constitutional energy reforms open investment in the nation's oil sector and other hydrocarbons to private companies through product sharing, profits sharing and license contracts, the main existing firm in the sector, PEMEX, remains state-controlled. Firms must also specify that hydrocarbons are owned by the Mexican State. If follows that questions in PMR indicators like 'Do national, state or provincial governments control at least one firm in the gas sector' capture no changes from 2013 to 2014.

Effect of the implementation of the secondary laws is expected to be captured by some indicators in the PMR in the near future, especially in the energy sector. In August 2014, the Ministry of Energy presented results of the 'Round Zero' or the allocations of the areas of exploration and fields of production that PEMEX will preserve (Presidencia de la República, 2014). Once the list is approved by the Ministry of Energy, it will only be legally possible for private sector contracts to be granted starting in in 2015. Consequently, questions like: 'What percentage of shares in the largest firm are owned by the national state or provincial governments' in the state control indicator do not reflect improvement in the PMR scores in this interim update. 


\section{WORKING PAPERS}

The full series of Economics Department Working Papers can be consulted at www.oecd.org/eco/workingpapers

1187. The conduct of monetary policy in the future: instrument use

(February 2015) By Kei-Ichiro Inaba, Rory O’Farrell, Lukasz Rawdanowicz and

Ane Kathrine Christensen

1186. A constant market share analysis of Spanish goods exports

(February 2015) By Alberto Gonzalez Pandiella

1185. Raising the economic participation of women in India - a new growth engine?

(February 2015) by Piritta Sorsa

1184. Improving health outcomes and health care in India

(January 2015) by Isabelle Joumard and Ankit Kumar

1183. Challenges and opportunities of India's manufacturing sector

(January 2015) by Isabelle Joumard, Urban Sila and Hermes Morgavi

1182. The heterogeneity of product market regulations

(December 2014) by Jean-Marc Fournier

1181. Implicit regulatory barriers in the EU single market: new empirical evidence from gravity models

(December 2014) by Jean-Marc Fournier, Aurore Domps, Yaëlle Gorin, Xavier Guillet and Délia Morchoisne

1180. Can pro-growth policies lift all boats? An analysis based on household disposable income (December 2014) by Orsetta Causa, Alain de Serres and Nicolas Ruiz

1179. Empirical evidence on the effects of environmental policy stringency on productivity growth (December 2014) by Silvia Albrizio, Tomasz Koźluk and Vera Zipperer

1178. The Indicators of the Economic Burdens of Environmental Policy Design - Results from the OECD Questionnaire

(December 2014) by Tomasz Koźluk

1177. Measuring Environmental Policy Stringency in OECD Countries-A Composite Index Approach (December 2014) by Enrico Botta and Tomasz Koźluk

1176. Do Environmental Policies Matter for Productivity Growth? Insights from new Cross-Country Measures of Environmental Policies

(December 2014) by Silvia Albrizio, Enrico Botta, Tomasz Koźluk and Vera Zipperer

1175. Making economic growth more socially inclusive

(December 2014) by Andrés Fuentes Hutfilter and Andreas Kappeler

1174. New tax and expenditure elasticity estimates for EU budget surveillance

(December 2014) by Robert W.R. Price, Thai-Thanh Dang and Yvan Guillemette 
1173. Moving towards a more dynamic business sector in Spain

(November 2014) by Alberto Gonzalez Pandiella

1172. Better harnessing talent and knowledge to boost sustainable medium-growth in Spain (November 2014) by David Haugh and Ben Westmore

1171. The internet economy - regulatory challenges and practices

(November 2014) by Isabell Koske, Rosamaria Bitetti, Isabelle Wanner and Ewan Sutherland

1170. A revival of the private rental sector of the housing market? Lessons from Germany, Finland, the Czech Republic and the Netherlands

(October 2014) by Rik de Boer and Rosamaria Bitetti

1169. Secular stagnation: evidence and implications for economic policy

(October 2014) by Łukasz Rawdanowicz, Romain Bouis, Kei-Ichiro Inaba and

Ane Kathrine Christensen

1168. Investment gaps after the crisis

(October 2014) by Christine Lewis, Nigel Pain, Jan Strasky and Fusako Menkyna

1167. Factors behind the decline in real long-term government bond yield

(October 2014) by Romain Bouis, Kei-Ichiro Inaba, Łukasz Rawdanowicz and

Ane Kathrine Christensen

1166. The effect of the global financial crisis on the OECD potential output

(October 2014) by Patrice Ollivaud and David Turner

1165. Determinants of households' investment in energy efficiency and renewables - evidence from the OECD Survey on household environmental behaviour and attitudes

(October 2014) by Nadia Ameli and Nicola Brandt

1164. Addressing high household debt in Korea

(September 2014) by Randall S. Jones and Myungkyoo Kim

1163. Reducing the high rate of poverty among the elderly in Korea

(September 2014) by Randall S. Jones and Satoshi Urasawa

1162. Promoting the financing of SMEs and start-ups in Korea

(September 2014) by Randall S. Jones and Myungkyoo Kim

1161. Fostering inclusive growth by promoting structural change in the business sector (September 2014) by Rauf Gönenç, Oliver Röhn, Vincent Koen and Fethi Ögünç

1160. Reducing macroeconomic imbalances in Turkey

(September 2014) by Oliver Röhn, Rauf Gönenç, Vincent Koen and Evren Erdoğan Coşar

1159. Reinvigorating the EU Single Market

(September 2014) by Jean-Marc Fournier. 